\title{
Emerging roles of Thelper 17 and regulatory $T$ cells in lung cancer progression and metastasis
}

\author{
Erin A. Marshall ${ }^{1 \dagger}$, Kevin W. $\mathrm{Ng}^{1+}$, Sonia H. Y. Kung ${ }^{1,5^{*}+}$, Emma M. Conway ${ }^{1,2}$, Victor D. Martinez ${ }^{1,2}$, \\ Elizabeth C. Halvorsen ${ }^{1}$, David A. Rowbotham¹, Emily A. Vucic ${ }^{1,2}$, Adam W. Plumb ${ }^{3,4}$, Daiana D. Becker-Santos ${ }^{1}$, \\ Katey S. S. Enfield ${ }^{1}$, Jennifer Y. Kennett ${ }^{1}$, Kevin L. Bennewith ${ }^{1,2}$, William W. Lockwood ${ }^{1,2}$, Stephen Lam', \\ John C. English', Ninan Abraham ${ }^{3}$ and Wan L. Lam ${ }^{1,25^{*}}$
}

\begin{abstract}
Lung cancer is a leading cause of cancer-related deaths worldwide. Lung cancer risk factors, including smoking and exposure to environmental carcinogens, have been linked to chronic inflammation. An integral feature of inflammation is the activation, expansion and infiltration of diverse immune cell types, including $C D 4^{+} T$ cells. Within this $T$ cell subset are immunosuppressive regulatory $T$ (Treg) cells and pro-inflammatory T helper 17 (Th17) cells that act in a fine balance to regulate appropriate adaptive immune responses.

In the context of lung cancer, evidence suggests that Tregs promote metastasis and metastatic tumor foci development. Additionally, Th17 cells have been shown to be an integral component of the inflammatory milieu in the tumor microenvironment, and potentially involved in promoting distinct lung tumor phenotypes. Studies have shown that the composition of Tregs and Th17 cells are altered in the tumor microenvironment, and that these two $\mathrm{CD}^{+} \mathrm{T}$ cell subsets play active roles in promoting lung cancer progression and metastasis. We review current knowledge on the influence of Treg and Th17 cells on lung cancer tumorigenesis, progression, metastasis and prognosis. Furthermore, we discuss the potential biological and clinical implications of the balance among Treg/Th17 cells in the context of the lung tumor microenvironment and highlight the potential prognostic function and relationship to metastasis in lung cancer.
\end{abstract}

Keywords: Th17, IL-17, Regulatory T cell, Treg, Lung cancer, Inflammation, Cancer immunology, Tumor microenvironment, Tumorigenesis, Prognosis

\section{Background}

\section{Lung cancer}

Lung cancer is the leading cause of cancer-related deaths worldwide, with a dismal five-year survival rate of $17 \%$ $[1,2]$. There are two major types of lung cancer: smallcell lung cancer (SCLC), which accounts for $\sim 15 \%$ of lung cancer patients, and non-small-cell lung cancer (NSCLC), comprising the remaining 85\% [3] (Fig. 1). The three major histological subtypes of NSCLC are adenocarcinoma $(\mathrm{AC})$, squamous cell carcinoma (SqCC)

\footnotetext{
*Correspondence: skung@bccrc.ca; wanlam@bccrc.ca

${ }^{\dagger}$ Equal contributors

'Department of Integrative Oncology, British Columbia Cancer Agency,

Vancouver, Canada

Full list of author information is available at the end of the article
}

and large cell carcinoma (LCC) (Fig. 1). AC is the most common histological subtype of lung cancer, accounting for approximately half of NSCLC cases (43.3\%; SEER Cancer Statistics Review, 1975-2012) and typically arises in the glandular epithelium of the lung periphery from either bronchioalveolar stem cells, club (formerly Clara) cells or type II pneumocytes [3-5] (Fig. 1). AC is also the predominant subtype that arises in patients who have never smoked [6]. By contrast, SqCC accounts for approximately $30 \%$ of NSCLC (22.6\%; SEER Cancer Statistics Review, 1975-2012), develops primarily in the central airways and segmental bronchi, and strongly associates with a history of smoking $[3,5,7]$ (Fig. 1). Regarding SCLC, the cell of origin has yet to be defined, but has been postulated to originate from differentiated neuroendocrine 


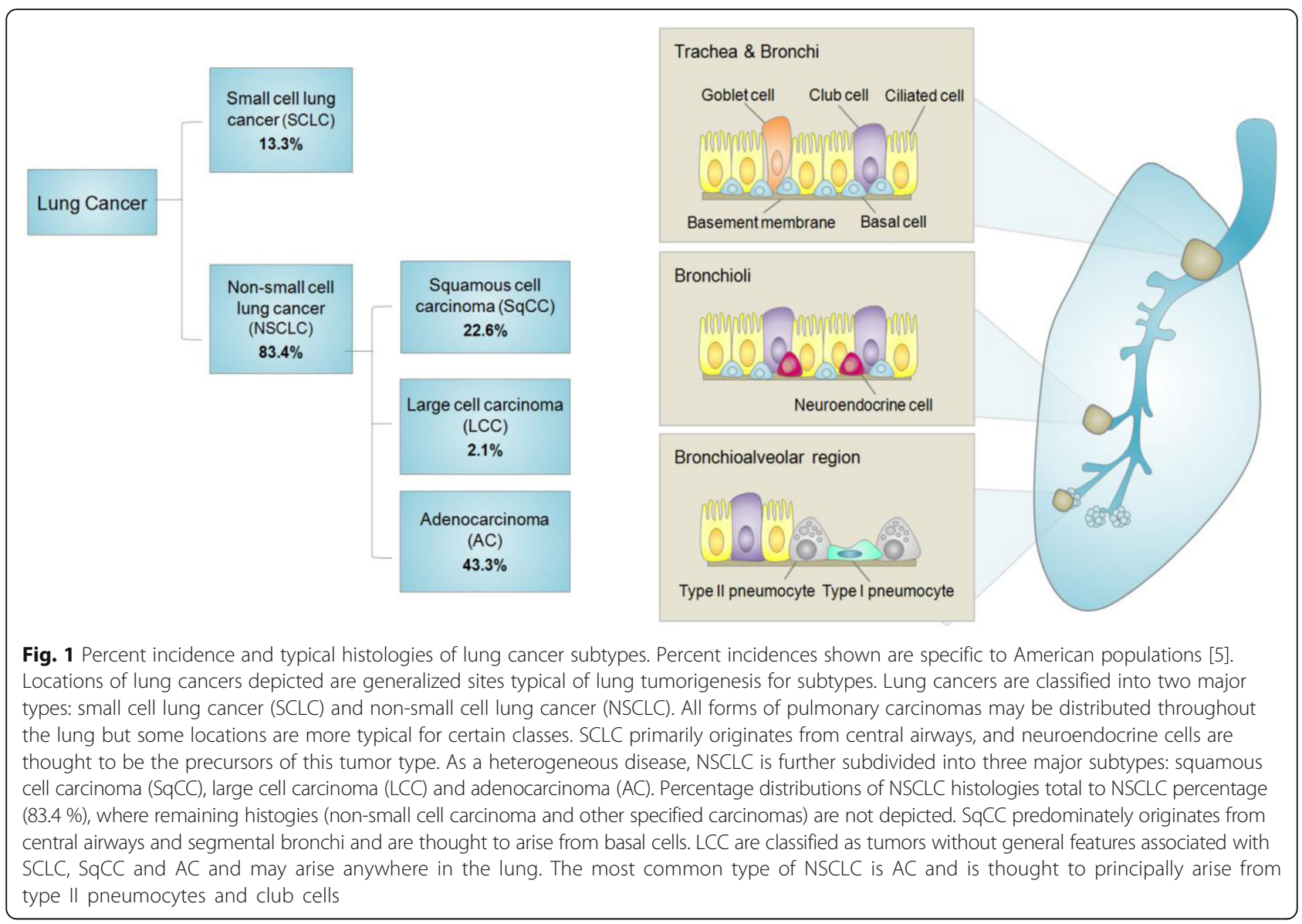

cell lineages, committed neuroendocrine progenitor cells or non-neuroendocrine cells that acquire neuroendocrine differentiation in the lung $[8,9]$ (Fig. 1).

\section{Inflammation and lung cancer}

Inflammation has been shown to promote cancer initiation and progression [10]. Specifically, inflammatory programs have been implicated in all aspects of cancer development, including malignant transformation, cell proliferation and survival, angiogenesis, invasion and metastasis [11]. Studies have indicated a strong relationship between lung cancer risk factors and alterations in inflammatory cytokine levels, oxidative stress markers and immune cell composition.

\section{Lung cancer risk factors, inflammatory cytokines and oxidative stress}

Exposure to tobacco smoke is a principal risk factor associated with lung cancer - smokers display a 14-fold increased risk of developing lung cancer compared to never smokers [12]. Although lung cancer is often viewed as a smoker's disease, if lung cancer in never smokers was considered as its own disease, it would rank as the seventh most common cause of cancer deaths worldwide and account for 300,000 deaths each year [6]. Other factors known to influence lung cancer risk include environmental carcinogens such as arsenic, radon, asbestos, air pollution, viral infection and genetic risk factors, including a family history of lung cancer [6, 13-16]. Furthermore, individuals with inflammatory lung disease, such as chronic obstructive pulmonary disease (COPD), have an elevated risk of developing lung cancer [17].

Cigarette smoking is known to drive altered local and systemic levels of inflammatory cytokines and reactive oxygen species (ROS) in the development of smoking related lung cancers. For example, inflammatory markers, including $\mathrm{C}$-reactive protein (CRP), chemokine ( $\mathrm{C}$ - $\mathrm{C}$ motif) ligand (CCL) 17, and CCL22, are elevated in the serum of former or current smokers compared to never smokers [18]. Furthermore, elevated levels of circulating inflammatory molecules CRP, CCL22, CCL17 and also chemokine (C-X-C motif) ligand (CXCL) 5, CXCL7, CXCL9, CXCL13 are associated with increased lung cancer risk in both current and former smokers [19]. Smokers with lung cancer have increased serum CCL20 levels, an inflammatory molecule shown to promote tumor cell proliferation and migration, that has also 
been significantly correlated with advanced disease and poor prognosis in lung cancer [20]. Surfactant protein D (SFTPD) is an important regulator of innate immunity, inflammation and oxidative stress secreted by type II pneumocytes in the airway; decreased expression of this protein in bronchoalveolar lavage (BAL) of smokers correlates with progression of bronchial dysplasia [21]. In addition to inflammatory cytokines and chemokines, ROS is also a major mediator of smoke induced damage, chronic inflammation and cancer development by promoting oxidative DNA damage and genomic instability [22]. Cigarette smoke is an enriched source of oxidants, which can enhance ROS generation by phagocytes to promote oxidative stress [23]. Increased recruitment of these phagocytes, including neutrophils and macrophages, is prominent in the lungs of smokers and patients with COPD compared to non-smokers [23]. Alternative oxidative stress markers, like extracellular superoxide dismutase (ECSOD), are elevated in the sputum of smokers [23, 24]. Taken together, alterations in cytokine and oxidative stress profiles of smokers indicate the presence of an important molecular link between smoking and lung inflammation.

In addition to smoking, exposure to airborne irritants and environmental carcinogens has been shown to induce lung inflammation. A well-documented example is asbestos, which refers to six unique silicate mineral fibers: chrysotile, amosite, crocidolite, tremolite, anthophyllite and actinolite. Inhaled asbestos fibers larger than $20 \mu \mathrm{m}$ are not efficiently phagocytosed and remain in lung tissue, where they induce fibrosis, inflammation and eventually, carcinogenesis [15, 25]. Most of the inflammation driven effects of asbestos exposure are a consequence of increased ROS production [26]. The presence of asbestos fibers induces a chronic inflammatory response, which generates significant ROS that contributes to subsequent DNA damage [26, 27]. Interestingly, different classes of asbestos fibers can induce changes in cytokines detectable in the serum, including cytokines characteristic of a T helper 17 (Th17) immune response, which will be discussed further below. In mice, intratracheal exposure to chrysotile asbestos induces a pattern of chronic inflammation associated with Th1 cytokines, while amphibole asbestos exposure induces both a Th1 and Th17 cytokine response [28]. Additionally, it has been shown that tremolite and erionite (a fiber with similar characteristics to amphibole asbestos) exposure caused increased IL-17 in splenocyte cultures, and erionite exposure induced elevated serum IL-17 levels in mice [29].

Finally, respiratory diseases involving chronic inflammation are linked with lung cancer risk. Of note, patients with the inflammatory lung disease COPD have up to a tenfold increase of lung cancer risk, and COPD is linked to activation of pro-tumorigenic inflammatory signaling pathways in immune cells [30]. Tumor and immune cells can communicate through nuclear factor kappa-light-chain-enhancer of activated B cells (NF-kB) and signal transducer and activator of transcription 3 (STAT3)-dependent cytokine production. Oncogenic activation of STAT3 and NF- $\mathrm{BB}$ induces cytokine production by tumor cells that can regulate immunosuppressive and tumor-promoting functions of tumor infiltrating immune cells via trans-activation of these same transcription factors [31]. This molecular pathway is noted as a potential mechanism for COPD-related lung cancer development [31-33]. Taken together, these studies highlight that lung cancer risk is influenced by changes in systemic and local inflammation. Moreover, altered compositions and activities of immune cells modulate the tumor microenvironment to promote lung cancer development.

\section{Inflammatory cells and lung cancer}

The biological process of inflammation relies on recruitment of diverse immune cell types. The inflammatory response depends on innate and adaptive immune cell activities to maintain tissue homeostasis [34]. However, immune cell infiltration is observed in tumors and can also promote cancer development, progression and metastasis [35] (Fig. 2). Immune cell composition in the tumor microenvironment may contribute to immune evasion and cancer development [36]. Innate and adaptive immune cells, including macrophages, neutrophils, natural killer (NK) cells and B cells, have been implicated in both anti-tumor and pro-tumor activities [37-43]. Specifically, the anti-tumor and pro-tumor roles of $\mathrm{T}$ cells in cancer development are currently of great interest. Therapeutic strategies targeting this adaptive immune cell type have been a major focus of recent immunotherapy development and applications, including for lung cancer treatment $[44,45]$.

$\mathrm{T}$ cells play diverse roles in the immune response and are highly relevant to lung cancer biology. $\mathrm{CD}^{+}$cytotoxic T lymphocytes (CTLs) facilitate immunosurveillance by $\mathrm{T}$ cell receptor (TCR) recognition of antigens bound to major histocompatibility complex (MHC)-I on antigen presenting cells and when activated, produce interferon gamma (IFN- $\gamma$ ), perforin and granzyme B that contribute to tumor cell cytolysis [46]. In addition to $\mathrm{CD}^{+} \mathrm{CTLs}$, various $\mathrm{CD} 4^{+} \mathrm{T}$ cells, including regulatory $\mathrm{T}$ (Treg) and $\mathrm{T}$ helper 17 (Th17) $\mathrm{CD}^{+} \mathrm{T}$ cell subsets have emerged as key players across a variety of diseases involving inflammation, including cancer. Both these $\mathrm{CD}^{+} \mathrm{T}$ cell subsets facilitate a pro-tumor environment through the promotion and maintenance of an immunosuppressive and pro-tumor inflammation environment that could favor tumorigenesis, cancer progression and metastasis. Treg and Th17 subsets are generally thought to play opposing roles in regulating immunity, where cell fate determineration arises from a balance of transcription 

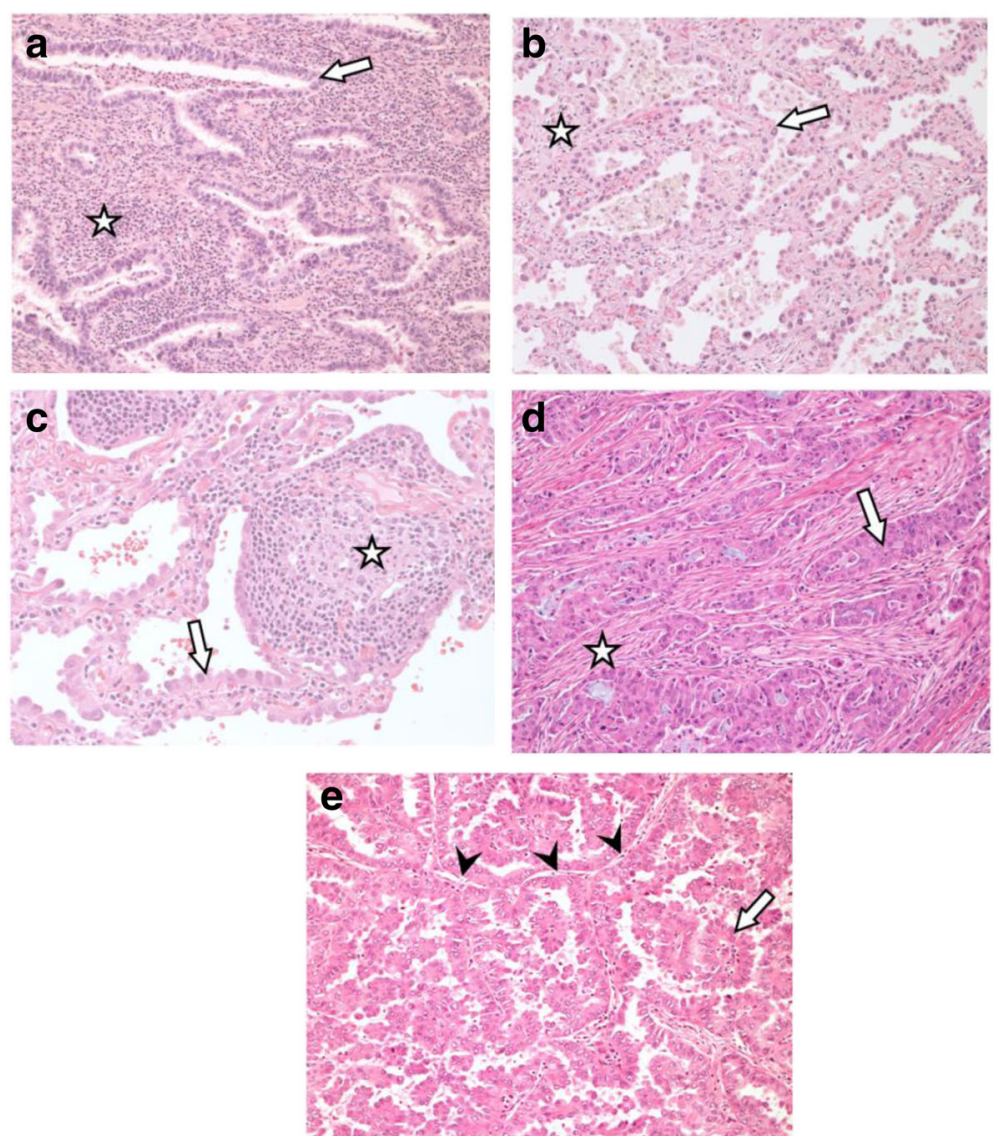

Fig. 2 Variable immune cell infiltration within pulmonary AC in patients. a Lepidic growth pattern showing wide expansion (star) of alveolar interstitium by a diffuse population of mononuclear inflammatory cells, principally lymphocytes. Arrow indicates neoplastic cells. b A similar tumor showing minimal interstitial expansion (star) with few infiltrating inflammatory cells. Arrow indicates neoplastic cells. c Another lepidic growth region of AC showing focal expansion of the interstitium by lymphoid follicular hyperplasia (star). Arrow indicates neoplastic cells. $\mathbf{d}$ AC with infiltrating acinar pattern showing a desmoplastic (fibroblastic scarring) reaction (star) with very few infiltrating lymphocytes. Arrow indicates neoplastic cells. e AC with a papillary pattern demonstrating alveolar septae (arrow heads) with no fibrous expansion and no infiltration by lymphocytes. Arrow indicates neoplastic cells. Original magnification for images 100x

factors governing $\mathrm{CD} 4^{+} \mathrm{T}$ cell differentiation and Treg and Th17 cell generation [47]. For instance, mouse and human studies show that expression of the transcription factor forkhead box P3 (FoxP3) represses Th17 transcription factors retinoic acid receptor-related orphan receptor gamma $\mathrm{t}(\mathrm{ROR} \gamma \mathrm{t})$ and ROR alpha (ROR $\alpha)$ to drive Treg differentiation $[48,49]$. Moreover, Th17 differentiation can occur when pro-inflammatory cytokines, including IL-6, IL-21 and IL-23, inhibit FoxP3 expression and subsequent repression of RORyt $[48,50]$. In addition to de novo generation of Tregs from FoxP3 ${ }^{-} \mathrm{T}$ cells, Tregs can also be generated under homeostatic or pathological conditions via proliferation of thymus-derived FoxP3 ${ }^{+}$cells [51, 52]. Additionally, a novel mechanism of Treg-dependent promotion of Th17 differentiation via IL-2 sequestration has been shown to promote IL-17-driven inflammation and tumorigenesis in colon cancer, highlighting the complex interplay between these two cell types in the context of cancer [53].

\section{Main text}

\section{Tregs and lung cancer}

By maintaining tolerance toward innocuous antigens, Tregs represent a vital component of the adaptive immune system, which functions to prevent autoimmunity and chronic inflammation [54, 55]. Tregs represent a phenotypically diverse cell lineage classified according to their site of differentiation, either in the thymus or at extrathymic sites [56]. Although not definitive, these cells are generally characterized as $\mathrm{CD} 4^{+} \mathrm{CD} 25^{\text {high }}$, and express the master regulatory transcription factor FoxP3 [57]. Tregs can induce immunosuppression through contact-dependent mechanisms such as the expression of cytotoxic T-lymphocyte-associated protein 4 (CTLA-4), programmed cell death 1 (PD-1), programmed deathligand 1 (PD-L1), lymphocyte-activation protein 3 (LAG-3), CD39/73 and neuropilin 1 (Nrp1), or through contactindependent mechanisms, including the sequestration of 
IL-2 and the production of the soluble immunosuppressive molecules IL-10, TGF- $\beta$, adenosine, prostaglandin $E_{2}$ $\left(\mathrm{PGE}_{2}\right)$ or galectin-1 [52, 55, 58-61] (Fig. 3a). In carcinogenesis, systemic expansion and intratumoral accumulation of immunosuppressive Tregs is thought to disrupt antitumor immunity, leading to the growth and metastasis of a variety of malignancies, including lung, breast, prostate and ovary $[54,56]$. Certain cell surface molecules have been shown to have stabilizing effects on the Treg cell population: CD39 (ectonucleoside triphosphate disphosphohydrolase 1; ENTPD1) has been shown to increase stability of $\mathrm{CD}^{+}{ }^{+} \mathrm{FoxP}^{+}$Tregs, contributing to their immunosuppressive function [62]. By suppressing anti-tumor effector cells, Tregs have emerged as active contributors to cancer progression $[63,64]$.

Tregs are implicated in the early stages of tumor development. In murine models of mutant Kras-driven AC, tumorigenesis was found to be Treg dependent,
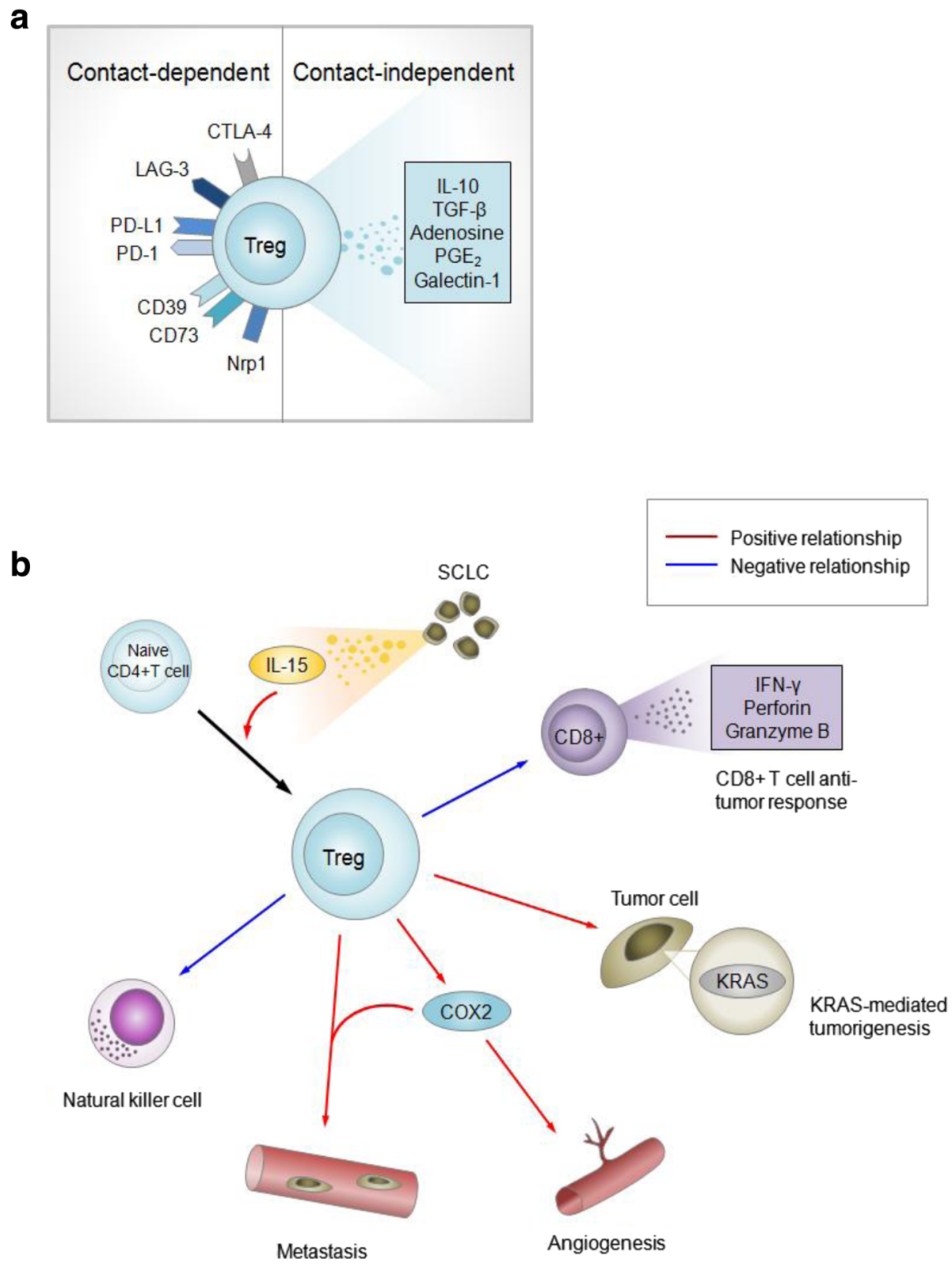

Fig. 3 Potential roles of Tregs associated with lung cancer development. a Contact-dependent and contact-independent mechanisms of Tregs in mediating tumorigenesis. All receptors shown are mouse specific. For humans, receptors shown are human-specific except for LAG3, CD73 and Nrp1, which are non-human specific or where human specificity remains undetermined. b Immunosuppressive and pro-tumorigenic processes in lung cancer development depend on quantitative relationships of Treg populations. Arrows indicate Treg-dependent processes, with red indicating positive relationships and blue indicating negative Treg-dependent relationships 
with Kras transgenic mice deficient in $\mathrm{FoxP}^{+}$Tregs developing $75 \%$ fewer lung tumors [65] (Fig. 3b). Tobacco carcinogen exposure increased pulmonary FoxP3 ${ }^{+}$lymphocytes prior to tumor development, suggesting a potential role for Tregs in the generation of a favorable niche for the development of lung tumors driven by Kras, mutations mainly found in smoker-related lung cancers [65].

Tregs influence the tumor microenvironment during the progression of lung cancers. Murine models of lung $\mathrm{AC}$ have demonstrated that Tregs may inhibit $\mathrm{CD} 8^{+} \mathrm{T}$ cell-mediated anti-tumor immunity (Fig. 3b), with the depletion of Tregs resulting in tumor cell death and elevated levels of granzyme A, granzyme B, perforin and IFN- $\gamma$ in infiltrating $\mathrm{CD}^{+} \mathrm{T}$ cells at early stages of tumorigenesis [66]. Further, the development of SCLC influences immunosuppressive activities of Tregs, where SCLC cell lines were reported to induce Treg generation from $\mathrm{CD}_{4}^{+} \mathrm{T}$ cells through the production of IL-15 [67] (Fig. 3b). In lung tumors, Tregs are also associated with expression of angiogenic and metastatic potentiator cyclooxygenase-2 (COX2), where elevated numbers of intratumoral Fox $\mathrm{P}^{+}$lymphocytes were positively correlated with high intratumoral expression of COX2, and can be induced by the tobacco carcinogen nicotinederived nitrosamine ketone (NNK) in mouse lungs [68, 69] (Fig. 3b).

Emerging evidence suggests that Tregs promote metastasis and metastatic tumor foci development [52]. A clinical study of NSCLC observed that Treg levels in peripheral blood increased with stage and were highest in patients with metastatic tumors [70]. It was also reported that Treg levels were elevated in metastatic lymph nodes compared to nonmetastatic lymph nodes in patients with $\mathrm{AC}[71,72]$. Mouse models of Lewis lung carcinoma reveal that Tregs inhibit NK cellmediated cytotoxicity in a TGF- $\beta$-dependent manner, and that depletion of Tregs contributes to enhanced NK cell antimetastatic activities [73] (Fig. 3b). Prognostically, the relative accumulation of Tregs in NSCLC tumors, and peripheral blood of SCLC patients (in relation to effector $\mathrm{T}$ cell populations) has been linked to increased risk of recurrence, and a high proportion of $\mathrm{FoxP}^{+}$lymphocytes in SCLC lung tumor biopsies correlates with poor survival $[67,68,74,75]$. Another study in NSCLC identified elevated levels of intratumoral $\mathrm{FoxP}^{+}$lymphocytes were associated with reduced recurrence-free survival [68].

Taken together, these findings underscore the relevance of Tregs in promoting lung cancer progression and metastasis. In a clinical setting, targeting the immune checkpoint molecules CTLA-4 and PD- 1 have recently received much attention in a variety of cancer types including lung cancers [76-79]. Ligation of these receptors leads to inhibition of $\mathrm{T}$ cell activation, particularly that of effector $\mathrm{CD}^{+}{ }^{+} \mathrm{T}$ cells. The anti-CTLA-4 immunotherapeutic agent ipilimumab has demonstrated promising results in improving SCLC and NSCLC patient outcomes, while nivolumab (anti-PD-1 therapy) has been approved by the Food and Drug Administration (FDA) for the treatment of advanced squamous and non-squamous NSCLC [76-80]. However, the response rate to nivolumab was only $20 \%$ in lung SqCC patients, and determining clinical biomarkers for treatment stratification for these available immunotherapies is a major focus [78, 81]. Currently, clinical biomarkers are limited for these treatments, as patients with little to no expression of these molecules in their lung tumors can still have beneficial therapeutic responses. For instance, patients harboring tumors with negative expression of the PD-1 ligand, PD-L1, can also benefit from anti-PD1/PDL1 therapies, suggesting that clinical use of PD-L1 positivity as selection criteria could exclude patients who could potentially benefit from these treatments [61]. Other factors are at play and the molecular mechanisms underlying Treg recruitment and their immunosuppressive functions in the lung tumor microenvironment require further study to improve patient therapy and outcomes.

\section{Th17 cells and lung cancer}

Th17 cells are a group of $\mathrm{CD} 4^{+} \mathrm{T}$ helper cells that are phenotypically distinct from Th1 and Th2 cells, and have been characterized in many inflammatory lung diseases, including COPD [82-89]. Th17 cells express the transcription factors ROR $\gamma$ t/RORC2 (mouse/human) and ROR $\alpha$, which drive Th17 differentiation and produce pro-inflammatory cytokines, including IL-17A, that modulate the tumor microenvironment [90, 91] (Fig. 4). The IL-17 cytokine family contributes to inflammation, cytokine and chemokine production, neutrophil recruitment in the context of lung inflammation and infection, and lung antitumor immunity [92, 93] (Fig. 4). Alterations to IL-17 and its signaling pathways are relevant to lung cancer development with IL-17 polymorphisms and epigenetic changes to the IL-17 signaling pathway correlating with increased predisposition to lung cancers $[89,94]$. Thus, Th17 cells are an integral component of the inflammatory milieu in the tumor microenvironment, and may be causally involved in promoting distinct lung tumor phenotypes.

The IL-17 family of cytokines is comprised of six members: IL-17A (also known as IL-17), IL-17B, IL-17C, IL-17D, IL-17E (also called IL-25) and IL-17 F [93, 95]. Th17 cells produce IL-17A and IL-17 F [93, 96]. Serum IL-17 levels strongly associate with lung cancer development. Serum IL-17 levels were found to be significantly higher in NSCLC compared to subjects without cancer, 


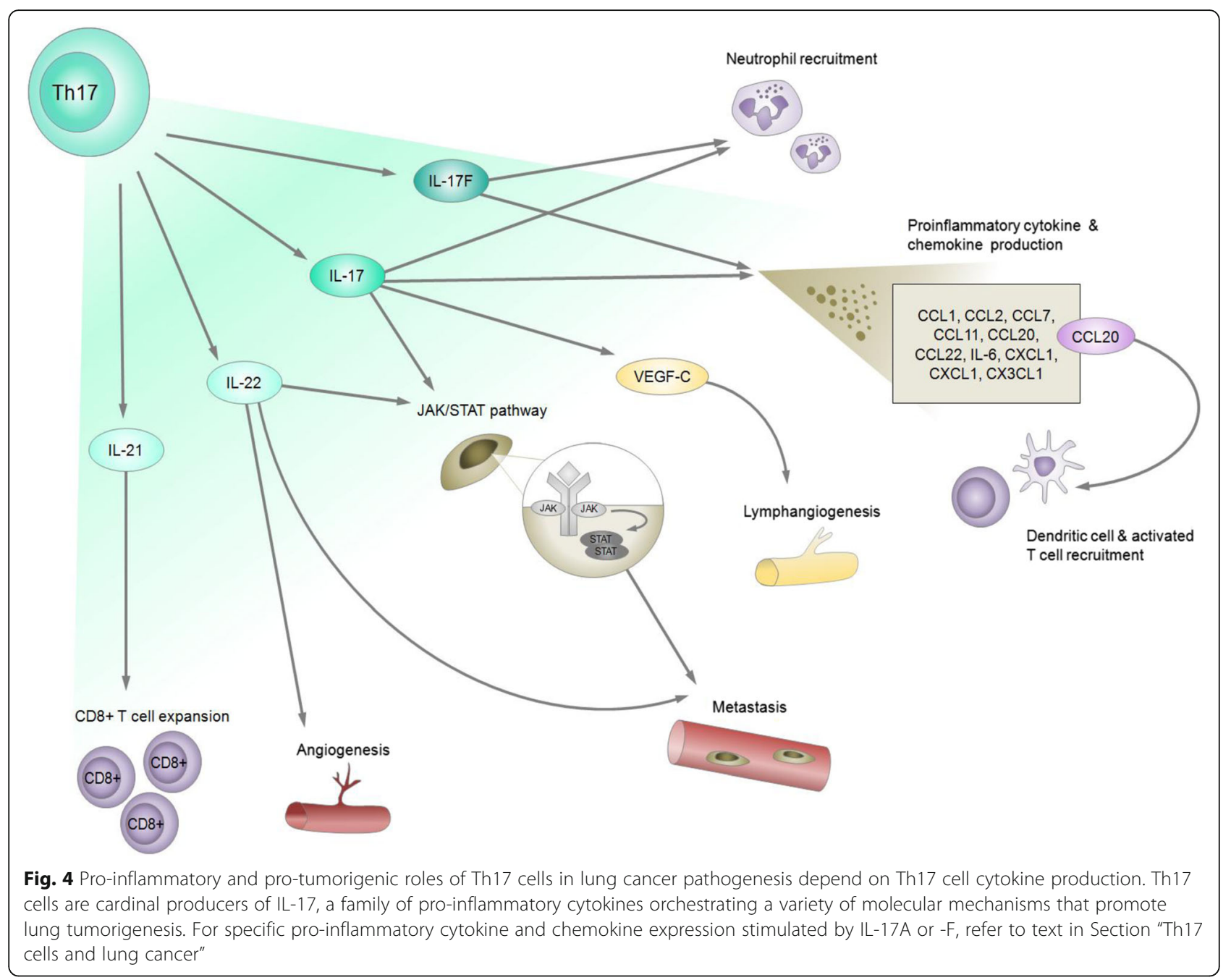

which could potentially offer an additional diagnostic marker for NSCLC [97]. IL-17 cytokines contribute to inflammation by facilitating pro-inflammatory cytokine and chemokine induction. Exogenous treatment of mouse embryonic fibroblasts (MEFs) with either IL-17A or IL-17 F induced greater expression of $I L-6, C X C L 1$, CCL2 and CCL7. Elevated expression of chemokines CCL7, CCL22, CCL20, CCL11 and chemokine (C-X3-C motif) ligand 1 (CX3CL1) were found in the lungs of transgenic mice chronically overexpressing IL-17A. In addition to upregulating these chemokines, elevated CCL1, CCL2 and CXCL1 expression was also present in the mouse lung epithelial cell line MLE12 upon exogenous IL-17A treatment [98] (Fig. 4).

Genetic variation and epigenetic alterations to the IL$17 \mathrm{~F}$ pathway may impact lung cancer development. Epigenetic analysis of DNA methylation patterns of COPD small airway epithelia has highlighted the relevance of the IL-17 F inflammatory response pathway in a disease significantly linked to lung cancer [89]. Specifically in
COPD small airways, $I L-17$ receptor $C$ (IL17RC) and CXCL1 (upstream and downstream components of the IL-17 F inflammatory pathway, respectively) were both identified to be hypermethylated and underexpressed, while DNA hypomethylation and overexpression of $\mathrm{col}$ ony stimulating factor 2 (CSF2), an IL-17 F-induced proinflammatory cytokine, was observed [89]. Many other genes in the IL-17 F inflammatory pathway were also found to be altered by DNA methylation in COPD small airways, and alterations of these genes are known to contribute to carcinogenesis [99] (Fig. 5, Table 1). Single nucleotide polymorphisms (SNPs) in $I L-17 F$ genes are significantly associated with lung cancer development. For example, the $I L-17$ F $7488 \mathrm{G}$ allele is associated with advanced stage or metastatic lung cancer in a Tunisian population [94]. COPD was characterized by increased Th17 cells $\left(\mathrm{CD}^{+} \mathrm{CD}^{+} \mathrm{IL}^{\left.-17 \mathrm{~A}^{+}\right)}\right.$in peripheral blood [100]. Likewise, high levels of Th17 cell cytokines have been observed in BAL of mouse models bearing oncogenic Kras-driven lung $\mathrm{AC}$ with concurrent induction of 


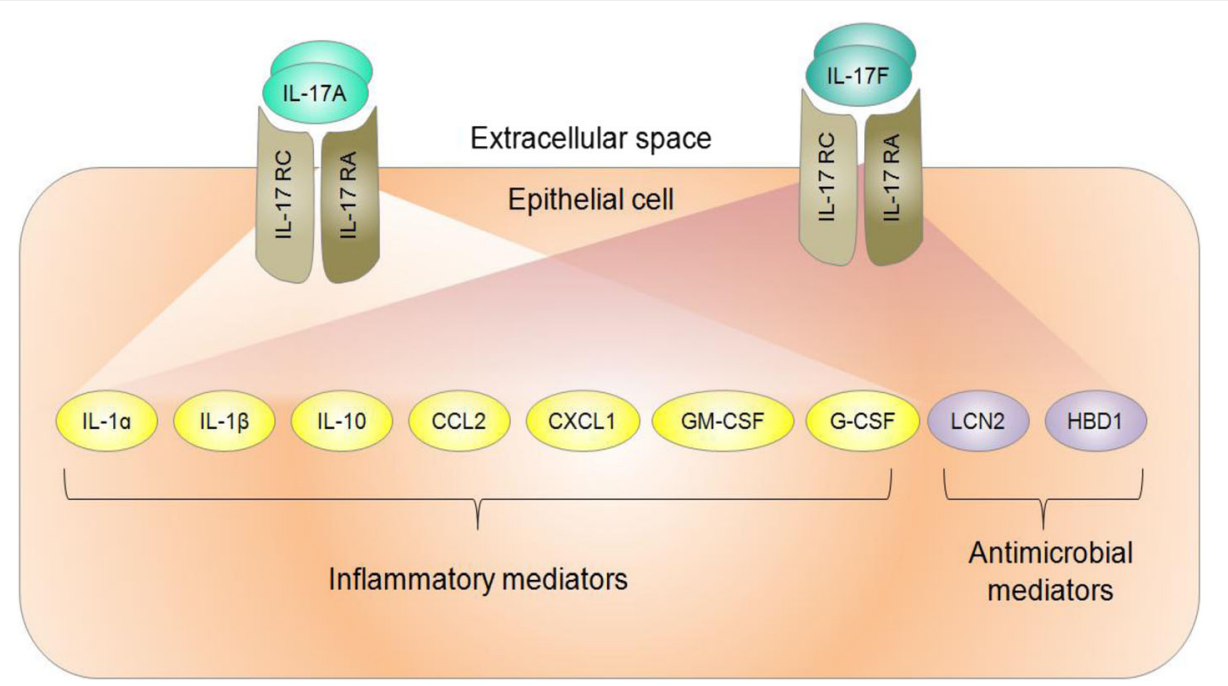

Fig. 5 The IL-17 F signaling pathway is epigenetically altered in malignant COPD and non-malignant COPD lung airway epithelial cells. Top disrupted downstream molecular components of the IL-17 F pathway are involved in mediating inflammatory and anti-microbial processes. Genes involved in IL-17A signaling pathways and that overlap with deregulations in the IL-17 F signaling pathway are also depicted. CCL2: Chemokine (C-C motif) ligand 2; CXCL1: chemokine (C-X-C motif) ligand 1; G-CSF: granulocyte colony-stimulating factor 3; CX3CL1: chemokine (C-X3-C motif) ligand 1, GM-CSF: granulocyte-macrophage colony-stimulating factor; HBD1: defensin beta 1; IL: interleukin; IL-17RA: interleukin 17 receptor A; IL- 17RC: interleukin 17 receptor C; LCN2: lipocalin 2

COPD-like inflammation through exposure to Haemophilus influenzae lysate (NTHi) [101]. $I l 17^{-1-}$ mice had reduced lung tumor numbers, as well as reduced tumor cell proliferation, angiogenesis, myeloid cell recruitment and expression of pro-inflammatory mediators (Il6, Cxcl2, Ccl2, Arg1, Csf3, Mmp7, Mmp12 and Mmp13) compared to $I l 17^{+/+}$mice (Fig. 6). Of note, reduction of lung tumor numbers occurred with IL-17 deficiency, but not with IL-17 F deficiency in lung tumor bearing mice [101]. Similarly, IL-17 has been shown to promote tumor growth in mice by increasing angiogenesis, metastasis and macrophage infiltration into tumors [102].

In malignant disease, increased expression of Th17 markers (IL-17A, ROR $\alpha 4$ and ROR $\gamma \mathrm{t}$ ) was observed in human lung $\mathrm{AC}$ compared to non-malignant lung tissue [103]. Th17 cells are key producers of IL-17, and this cytokine is known to contribute to the induction of lung cancer prometastatic factor expression. Elevated expression of IL-17 in peripheral blood was significantly correlated with TNM (tumor node metastasis) stage and

Table 1 Examples of genes in the IL-17 F pathway epigenetically altered in COPD and their respective roles in cancer

\begin{tabular}{|c|c|c|}
\hline Epigenetically disrupted in COPD & Roles in cancer & References \\
\hline IL-1a & $\begin{array}{l}\text { Tumor cell-derived IL-1a increases tumor immunogenicity } \\
\text { Precursor IL-1a from necrotic tumor cells promotes inflammation }\end{array}$ & [155] \\
\hline IL-1 $\beta$ & Polymorphisms associated with overall cancer risk & [156] \\
\hline IL-10 & 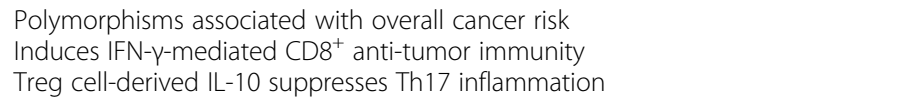 & [157-159] \\
\hline CCL2 & $\begin{array}{l}\text { Promotes metastasis and angiogenesis } \\
\text { Recruits monocytes and macrophages contributing to inflammation }\end{array}$ & {$[160,161]$} \\
\hline CXCL1 & $\begin{array}{l}\text { Promotes metastasis, angiogenesis and cell proliferation } \\
\text { Induces constitutive NF-kB activation } \\
\text { Facilitates tissue damage }\end{array}$ & {$[162,163]$} \\
\hline GM-CSF/G-CSF & $\begin{array}{l}\text { Promotes angiogenesis } \\
\text { G-CSF contributes to myeloid derived suppressor cell recruitment at tumor site }\end{array}$ & {$[164,165]$} \\
\hline LCN2 & $\begin{array}{l}\text { Induces epithelial-mesenchymal transition (EMT) and promotes metastasis } \\
\text { Promotes cell survival through iron sequesteration }\end{array}$ & {$[166,167]$} \\
\hline HBD1 & $\begin{array}{l}\text { Disrupts cell membrane and activates caspases in tumor cells } \\
\text { Frequently lost in cancers, including prostate and renal cancers } \\
\text { Recruits immature dendritic cell and memory } T \text { cell }\end{array}$ & {$[168,169]$} \\
\hline
\end{tabular}




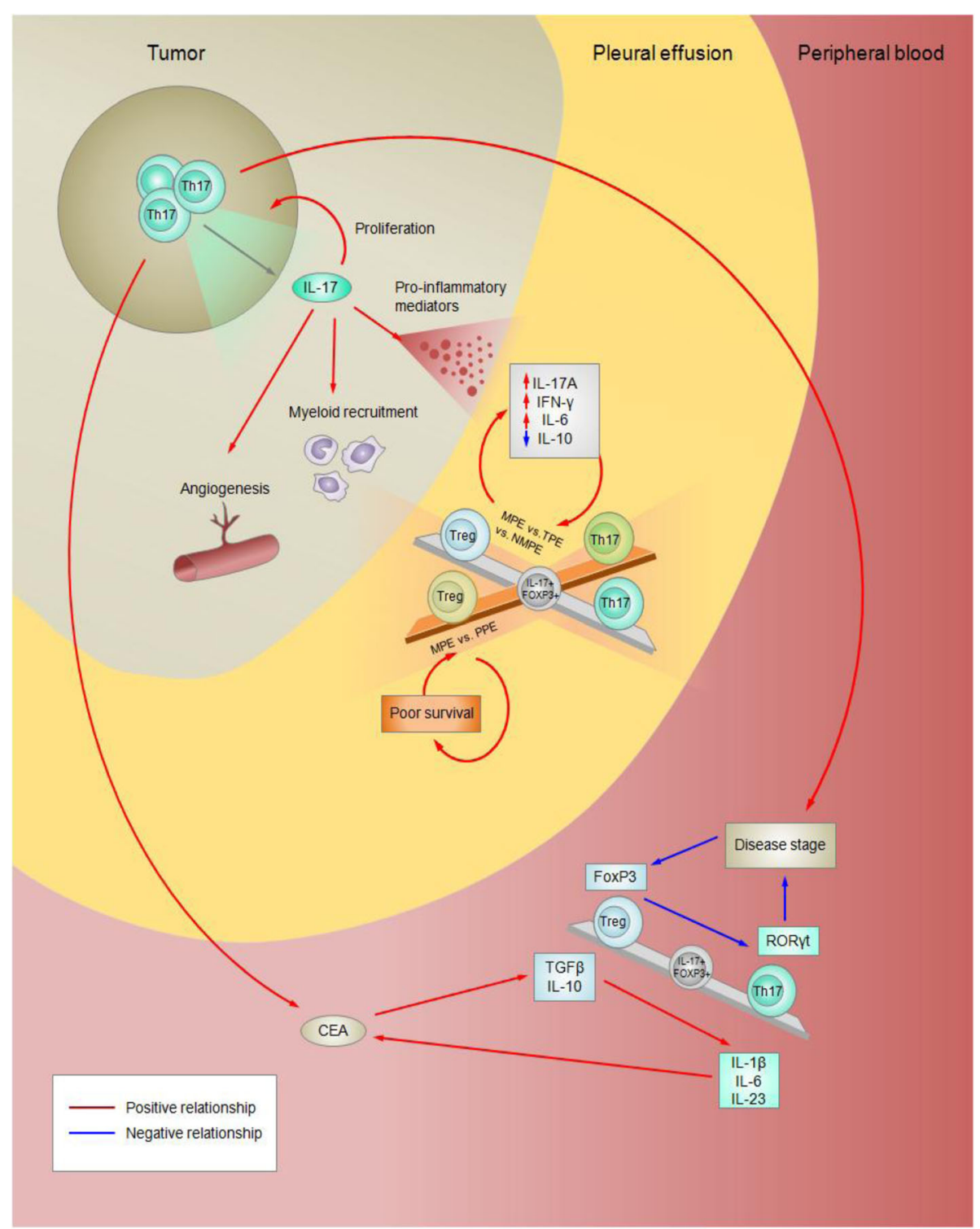

Fig. 6 Treg/Th17 ratios are context-dependent in lung cancer patients and associate with disease pathogenesis and outcome of lung cancers. Blue arrows indicate negative relationships, and red arrows indicate positive relationships. Balance beams indicate correlation among Treg and Th17 cell subsets, with intermediate $\mathrm{IL}-17^{+} \mathrm{FoxP} 3^{+}$phenotypes present at the centre to indicate that these cells may contribute to cell ratios. The Treg/Th17 ratio has been primarily assessed in pleural effusion and peripheral blood in malignant and non-malignant pleural effusions. MPE: malignant pleural effusion; NMPE: non-malignant pleural effusion derived from non-chronic diseases; PPE: parapneumonic effusion; TPE: Tuberculous pleural effusion

increased expression of IL-17 receptor (IL-17RC) in NSCLC tumor cells was associated with invasive potential [104]. Treatment of NSCLC cell lines A549 and H520 with IL-17 resulted in increased phosphorylation of STAT3, which upregulated prometastatic factor production including vascular endothelial growth factor (VEGF) [105]. While IL-17 upregulation of STAT3 was shown to be mediated by IL-6 other cancer types $[106,107]$, this phenomena did not hold true in this case [105]. As a mechanism of lymph node metastasis, IL-
17 can promote lymphangiogenesis by upregulating the expression of the lymphangiogenic factor vascular endothelial growth factor-C (VEGF-C) in murine lung cancer cells [108, 109] (Fig. 4). In humans, increased density of IL-17 positive cells in NSCLC tumors correlated with lymphatic vessel density [110]. Furthermore, loss of IL-17 has been shown to reduce metastases. Studies have shown that when challenged with Lewis lung carcinoma cells, IL-17 knockout mice had reduced number of metastatic nodules in lungs and improved survival 
compared to wild-type mice [104, 111]. Taken together, these studies reveal potential mechanistic and functional effects of IL-17 in cancer progression and metastasis.

Th17 cells produce other cytokines in addition to IL-17, including IL-22, which is also associated with lung cancer. IL-22 contributes to pro-survival signaling, angiogenesis and metastasis, part of which may be associated with its activation of STAT3 signaling pathway in cancer cells [112] (Fig. 4). High levels of IL-22 have been detected both locally in primary tumors and malignant pleural effusions (MPEs) and systemically in serum of NSCLC patients [113].

Th17 cells have complex biological functions and evidence suggests that these cells may paradoxically also contribute to anti-tumor immunity. With infusion of in vitro-generated Th17 cells, lungs of mice bearing B16 melanoma tumors had elevated dendritic cell and activated $\mathrm{T}$ cell recruitment, as well as elevated CCL20 and CCL2 expression, chemokines known to recruit these anti-tumor immune cells [114]. Increased IL-21 levels, also produced by Th17 cells, can induce tumor regression through expansion of $\mathrm{CD}^{+}$tumor-infiltrating lymphocytes in NSCLC as well as ovarian cancer and melanoma [115, 116] (Fig. 4). Moreover, high counts of pleural Th17 cells are associated with increased survival of NSCLC (lung AC and SqCC histologies) in human MPEs [117]. These studies reveal differential functions of Th17 cells, thus further investigation into their biological roles and clinical relevance in cancer development is warranted.

\section{Quantitative relationships between Th17s and Tregs in lung cancer prognosis}

While various immune cell populations have been studied extensively in the context of cancer biology, the field has primarily focused on individual cell populations. More recently, cancer immunology has shifted towards a more integrated understanding of potential interactions among immune cell populations within the tumor microenvironment, including a focus on cellular ratios, crosstalk and phenotype plasticity in the context of cancer prognosis. Advancements in this framework include the development of an immunoscore as a potential component of cancer classification with prognostic relevance across a number of different tumor types, including NSCLC [118-121]. In addition to lung cancer, changes to Treg/Th17 levels have been observed in hematological and other solid tumor types in addition to autoimmune diseases and viral and bacterial infections, indicating that the balance of these two subsets plays an important role in regulating inflammation and cancer development [122-124]. Although both Treg and Th17 cells exert a diverse set of cancer-related functions (Figs. 3 and 4), these $\mathrm{CD} 4^{+} \mathrm{T}$ cell subsets may have opposing prognostic values in lung cancer, with a higher ratio of Tregs to Th17s correlating with more aggressive and advanced-staged malignancies $[125,126]$. The balance of Treg and Th17 cells has been assessed in inflammation resulting from autoimmune disease, viral infections and bacterial infections [127-134]. In addition, Th17 and Treg cells are broadly considered to play pro- and anti-inflammatory roles, respectively, though it should be noted $\mathrm{T}$ cell plasticity allows for a functional continuum between these two $\mathrm{CD} 4^{+} \mathrm{T}$ cell subsets $[135,136]$. In summation, the balance of these two $\mathrm{CD}^{+} \mathrm{T}$ cell subsets at local tumor and systemic sites appears to be strongly associated with lung cancer development, progression and prognosis.

The Treg/Th17 ratio and lung cancer prognosis has been assessed in peripheral blood. Peripheral blood of NSCLC patients is characterized by a significantly higher percentage of Th17 $\left(\mathrm{CD} 4^{+} \mathrm{IL}-17^{+}\right)$and Treg cells $\left(\mathrm{CD} 4^{+} \mathrm{CD} 25\right.$ ${ }^{+} \mathrm{FoxP}^{+}$) compared to individuals without cancer. However, in NSCLC patients, the levels of these two $\mathrm{CD}^{+}{ }^{+} \mathrm{T}$ cell subsets were inversely correlated in peripheral blood [137] (Fig. 6). Serum Th17 cells are known to positively correlate with IL-1 $\beta$, IL-6, IL-23, while Tregs are known to positively correlate with TGF- $\beta 1$ and IL-10 [137] (Fig. 6). NSCLC patients with Stage IV disease had higher Treg/ Th17 ratios compared to patients with Stage I-III disease (Fig. 6). Conversely, the ratio was determined in another study to inversely correlate with serum levels of carcinoembryonic antigen (CEA), an oncofetal marker elevated in lung cancers with poor prognosis [137]. These studies highlight the variability of $\mathrm{CD}^{+} \mathrm{T}$ cell ratios in cancer progression, which certainly warrants further exploration [126].

In addition to assessing Treg/Th17 ratios in a systemic context in peripheral blood, proportions of these $\mathrm{CD} 4^{+}$ $T$ cell subsets have been characterized in biological fluids that are local to the lung, including pleural fluid (Table 2). Malignant and non-malignant pleural effusions (NMPE) derived from chronic inflammatory lung diseases, such as lung cancer and tuberculosis, have lower Treg and higher Th17 levels compared to nonchronic pleural effusions [138]. However, upon stimulation, $\mathrm{CD} 4^{+} \mathrm{T}$ cells in MPE secrete higher levels of IFN- $\gamma$, IL- 6 and IL-17A and lower levels of IL-10 compared to that of non-malignant tuberculous pleural effusions (TPE) over time, suggesting that Th17s may maintain a pro-inflammatory environment in the pleural cavity of lung cancer patients [138] (Fig. 6). Conversely, an elevated Treg/Th17 ratio was found in MPEs when compared to NMPEs, such as parapneumonic pleural effusions (PPE) [139]. Furthermore, MPEs from lung cancer patients with a high Treg/Th17 ratio were found to correlate with poor survival [139]. These differences may be partially accounted for by the complex roles of inflammation in pro-tumor and anti-tumor activities during the course of cancer development [140]. 
Table 2 Characterization of Treg/Th17 ratios in malignant pleural effusions

\begin{tabular}{|c|c|c|}
\hline Pleural effusion type compared & Observed characteristics of malignant pleural effusion (Relative to pleural effusion type compared) & References \\
\hline Parapneumonic & $\begin{array}{l}\uparrow \text { Treg }\left(\mathrm{CD}^{+} \mathrm{CD}_{2} 5^{+} \mathrm{FoxP3}^{+}\right) / \mathrm{Th}_{17}\left(\mathrm{CD} 4^{+} \mathrm{IL}-17^{+}\right) \text {ratio } \\
\uparrow \text { Foxp3/RORyt ratio }\end{array}$ & [139] \\
\hline Malignant (with low Treg/Th17 ratio) & $\downarrow$ Overall survival with high Treg/Th17 in malignant pleural effusions & \\
\hline Non-chronic diseases & 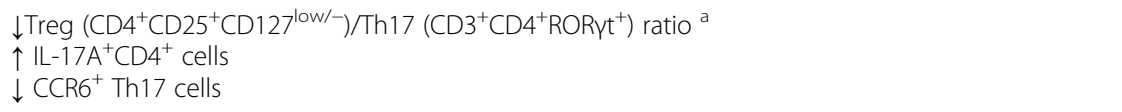 & [138] \\
\hline Tuberculous & $\begin{array}{l}\text { No significant difference in Treg }\left(\mathrm{CD}^{+}{ }^{+} \mathrm{CD} 25^{+} \mathrm{CD} 127^{\text {low/- }}\right) / \text { Th17 }_{\left(\mathrm{CD} 3^{+} \mathrm{CD} 4^{+} \mathrm{ROR}_{\mathrm{rt}}{ }^{+}\right) \text {ratio }} \\
\uparrow \mathrm{IL}-17 \mathrm{~A}^{+} \mathrm{CD} 4^{+} \text {cells } \\
\downarrow \text { CCR6 }{ }^{+} \text {Th17 cells }\end{array}$ & \\
\hline
\end{tabular}

${ }^{a}$ For consistency, cell ratios are presented as Treg/Th17

As evidenced by the studies mentioned above, the Treg/Th17 ratio has been primarily assessed in peripheral blood and pleural effusion samples. Collection of liquid biopsies requires less invasive procedures and are advantageous for longitudinal studies, as sampling can be conducted at multiple time points [141]. Future longitudinal studies will be very valuable to elucidating potential temporal relationships of these cell types during lung cancer pathogenesis and their clinical relevance. Treg and Th17 cell levels have been assessed in lung tumor biopsies, although these cell types are typically assessed individually using single markers on tissues sections, and Treg/Th17 ratios have not yet been reported for lung tumors. Part of the difficulty in assessing Tregs and Th17 cells in solid tumors is that both cell types are most accurately identified using multiple phenotypic markers and are therefore more amenable to analyses by single cell analytical methods, such as flow cytometry [142]. The advancement of multispectral imaging analyses of tissue sections may allow for Treg/ Th17 ratio assessment in lung tumour biopsies in the future, while also providing extended insights into the clinical relevance of the spatial relationships of immune cells within the tumor microenvironment [143, 144].

While Th17s and Tregs have unique roles in the tumor microenvironment, interpretations of this ratio

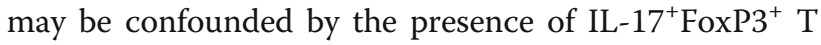
cells, an intermediate Treg/Th17 phenotype that may be relevant to tumorigenesis [145] (Fig. 6). $\mathrm{IL}^{-17^{+} \mathrm{FoxP}^{+} \mathrm{T}}$ cells may be generated from cytokine-dependent reprogramming of Tregs [146]. IL- $17^{+} \mathrm{FoxP}^{+} \mathrm{T}$ cells have been implicated in autoimmune disease and solid cancer development, including inflammatory bowel disease and esophageal, colon and lung cancers [147-150]. In lung cancer, a CD45RA ${ }^{-} \mathrm{CD} 45 \mathrm{RO}^{+}$FoxP3 ${ }^{\text {hi }}$ subset enriched in NSCLC is characterized by increased ROR $\gamma \mathrm{t}$ and IL-17 expression [151]. Elucidation of specific molecular features and functions that $\mathrm{IL}-17^{+} \mathrm{FoxP}^{+} \mathrm{T}$ cells possess may reveal how this intermediate cell type influences inflammation in the tumor microenvironment, and may improve understanding of the Treg/Th17 ratio in cancer prognosis. The link between the balance of Tregs/Th17 cells and lung cancer prognosis underscores the clinical relevance of these cell types as biomarkers and potential therapeutic targets. With the current development of Th17 and Treg-targeted therapies, further studies assessing the complex roles of these immune cell types in lung cancer are needed if they are to be implemented in the clinic as a novel lung cancer treatment strategy [152-154].

\section{Conclusions}

Inflammation mediated by infiltrating immune cells plays a key role in cancer pathogenesis. Among these, $\mathrm{T}$ cells display critical and diverse roles in the establishment and suppression of inflammation within the tumor microenvironment. These include Tregs and Th17s, $\mathrm{CD} 4^{+} \mathrm{T}$ cells which have been observed to mechanistically promote tumorigenesis, cancer progression and metastasis through immunosuppressive and pro-inflammatory functions. Specifically, Treg and Th17 cells in the tumor microenvironment modulate cytokine and chemokine production, promote immune cell recruitment and help regulate anti-tumor and pro-tumor immune cell activation states. Altered levels of these immune cell populations and their respective functions can facilitate lung cancer progression and metastasis. Furthermore, the balance of these $\mathrm{CD}_{4}^{+} \mathrm{T}$ cell populations at local and systemic sites may be clinically relevant in evaluating lung cancer prognosis. Further investigations are warranted to fully characterize the mechanistic effects and prognostic value of these immune cell populations in the context of cancer.

\section{Abbreviations}

AC: Adenocarcinoma; BAL: Bronchoalveolar lavage; CCL: Chemokine (C-C motif) ligand; CEA: Carcinoembryonic antigen; COPD: Chronic obstructive pulmonary disease; COX2: Cyclooxygenase 2; CRP: C-reactive protein;

CSF: Colony-stimulating factor; CTL: Cytotoxic T lymphocyte;

CXCL: Chemokine (C-X-C motif) ligand; IFN-ץ: Interferon gamma;

IL: Interleukin; JAKJSTAT: Janus kinase/signal transducer and activator of transcription; MPE: Malignant pleural effusion; NF-kB: Nuclear factor kappalight-chain-enhancer of activated B cells; NK: Natural killer; NNK: Nicotinederived nitrosamine ketone; NSCLC: Non-small cell lung cancer; NTHi: Nontypeable Haemophilus influenzae; RORyt: Retinoic acid receptorrelated orphan receptor gamma t; ROS: Reactive oxygen species; SCLC: Small cell lung cancer; SqCC: Squamous cell carcinoma; TGF- $\beta$ : Transforming growth factor beta; Th: T helper 


\section{Acknowledgements}

Not applicable.

\section{Funding}

This work was supported by grants from the Canadian Institutes for Health Research (CIHR, FDN-143345, MOP-123273, MOP-110949), the Canadian Cancer Society (CCSRI \#702535 and \#702520), the National Sanitarium Association and the Terry Fox Research Institute. E.A.M. is supported by a British Columbia Cancer Studentship; S.H.Y.K., E.C.H., D.A.R, E.A.V. and K.S.S.E. by CIHR Frederick Banting and Charles Best Canada Graduate Scholarships and Four Year Doctoral Fellowships from the University of British Columbia. D.D.B.S is supported by a Vanier Canada Scholarship and a Killiam Doctoral Scholarship. K.L.B and W.W.L. are Michael Smith Foundation for Health Research Biomedical Research Scholars.

\section{Availability of data and materials}

Not applicable.

\section{Authors' contributions}

EAM, KWN and SHYK performed literature search and drafted the manuscript. SHYK and JCE produced the figures and illustrations. All authors contributed to the design of the article, participated in the writing and analysis of information, and approved the final version to be published. KLB, WWL, SL, $N A$ and $W L L$ are the principal investigators.

\section{Authors' information}

E.A.M., K.W.N and S.H.Y.K. contributed equally to the preparation of this article. This manuscript was authored with critical input from leading experts in various aspects of lung cancer biology. A.W.P, E.C.H., E.M.C., K.W.B., K.W.N. and N.A. provided expertise in immunology. J.C.E. provided expertise in lung cancer histopathology. D.A.R., D.D.B.S., E.A.V., K.S.S.E., S.L., V.D.M., W.L.L. and W.W.L. provided expertise in lung tumor molecular biology.

\section{Competing interests}

The authors declare that they have no competing interests.

\section{Consent for publication}

Not applicable.

\section{Ethics approval and consent to participate}

\section{Not applicable.}

\section{Author details}

'Department of Integrative Oncology, British Columbia Cancer Agency, Vancouver, Canada. ${ }^{2}$ Department of Pathology and Laboratory Medicine, University of British Columbia, Vancouver, Canada. ${ }^{3}$ Departments of Microbiology and Immunology, University of British Columbia, Vancouver, Canada. ${ }^{4}$ Department of Zoology, University of British Columbia, Vancouver, Canada. ${ }^{5}$ British Columbia Cancer Research Centre, Vancouver, Canada.

Received: 14 July 2016 Accepted: 18 October 2016

Published online: 27 October 2016

\section{References}

1. Jemal A, Bray F, Center MM, Ferlay J, Ward E, Forman D. Global cancer statistics. CA Cancer J Clin. 2011;61(2):69-90.

2. Cancer facts and figures. [http://www.cancer.org/acs/groups/content/ @editorial/documents/document/acspc-044552.pdf]. Accessed 13 Jan 2016.

3. Pikor LA, Ramnarine VR, Lam S, Lam WL. Genetic alterations defining NSCLC subtypes and their therapeutic implications. Lung Cancer. 2013;82(2):179-89.

4. Kim CF, Jackson EL, Woolfenden AE, Lawrence S, Babar I, Vogel S, Crowley D, Bronson RT, Jacks T. Identification of bronchioalveolar stem cells in normal lung and lung cancer. Cell. 2005;121(6):823-35.

5. Howlader N, Noone AM, Krapcho M, Garshell J, Miller D, Altekruse SF, Kosary CL, Yu M, Ruhl J, Tatalovich Z, Mariotto A, Lewis DR, Chen HS, Feuer EJ, Cronin KA, editors. SEER Cancer Statistics Review, 1975-2012. Bethesda: National Cancer Institute; 2015. http://seer.cancer.gov/csr/1975_2012/, based on November 2014 SEER data submission, posted to the SEER web site.

6. Sun S, Schiller JH, Gazdar AF. Lung cancer in never smokers-a different disease. Nat Rev Cancer. 2007;7(10):778-90.
7. Gazdar AF, Brambilla E. Preneoplasia of lung cancer. Cancer Biomark. 2010; 9(1-6):385-96.

8. Park KS, Liang MC, Raiser DM, Zamponi R, Roach RR, Curtis SJ, Walton Z, Schaffer BE, Roake CM, Zmoos AF, et al. Characterization of the cell of origin for small cell lung cancer. Cell Cycle. 2011;10(16):2806-15.

9. Semenova EA, Nagel R, Berns A. Origins, genetic landscape, and emerging therapies of small cell lung cancer. Genes Dev. 2015;29(14):1447-62.

10. Hanahan D, Weinberg RA. Hallmarks of cancer: the next generation. Cell. 2011;144(5):646-74.

11. Gomes M, Teixeira AL, Coelho A, Araujo A, Medeiros R. The role of inflammation in lung cancer. Adv Exp Med Biol. 2014;816:1-23.

12. Sato M, Shames DS, Gazdar AF, Minna JD. A translational view of the molecular pathogenesis of lung cancer. J Thorac Oncol. 2007;2(4):327-43.

13. Hajdu SI. Much overlooked causes of lung cancer. Ann Clin Lab Sci. 2011; 41(1):97-101.

14. Martinez VD, Vucic EA, Lam S, Lam WL. Arsenic and lung cancer in neversmokers: lessons from Chile. Am J Respir Crit Care Med. 2012;185(10):1131-2.

15. Hubaux R, Becker-Santos DD, Enfield KS, Lam S, Lam WL, Martinez VD. Arsenic, asbestos and radon: emerging players in lung tumorigenesis. Environ Health. 2012;11:89.

16. Hubaux R, Becker-Santos DD, Enfield KS, Rowbotham D, Lam S, Lam WL, Martinez VD. Molecular features in arsenic-induced lung tumors. Mol Cancer. 2013;12:20.

17. Houghton AM. Mechanistic links between COPD and lung cancer. Nat Rev Cancer. 2013;13(4):233-45.

18. Shiels MS, Katki HA, Freedman ND, Purdue MP, Wentzensen N, Trabert B, Kitahara CM, Furr M, Li Y, Kemp TJ, et al. Cigarette smoking and variations in systemic immune and inflammation markers. J Natl Cancer Inst. 2014; 106(11):dju294.

19. Shiels MS, Pfeiffer RM, Hildesheim A, Engels EA, Kemp TJ, Park JH, Katki HA, Koshiol J, Shelton G, Caporaso NE, et al. Circulating inflammation markers and prospective risk for lung cancer. J Natl Cancer Inst. 2013;105(24):1871-80.

20. Wang GZ, Cheng X, Li XC, Liu YQ, Wang XQ, Shi X, Wang ZY, Guo YQ, Wen $Z S$, Huang YC, et al. Tobacco smoke induces production of chemokine CCL20 to promote lung cancer. Cancer Lett. 2015;363(1):60-70.

21. Sin DD, Man SF, McWilliams A, Lam S. Surfactant protein D and bronchial dysplasia in smokers at high risk of lung cancer. Chest. 2008;134(3):582-8.

22. Filaire E, Dupuis C, Galvaing G, Aubreton S, Laurent H, Richard R, Filaire M. Lung cancer: what are the links with oxidative stress, physical activity and nutrition. Lung Cancer. 2013;82(3):383-9.

23. Rahman I. Pharmacological antioxidant strategies as therapeutic interventions for COPD. Biochim Biophys Acta. 2012;1822(5):714-28.

24. Regan EA, Mazur W, Meoni E, Toljamo T, Millar J, Vuopala K, Bowler RP, Rahman I, Nicks ME, Crapo JD, et al. Smoking and COPD increase sputum levels of extracellular superoxide dismutase. Free Radic Biol Med. 2011;51(3): 726-32.

25. Xu A, Huang X, Lien YC, Bao L, Yu Z, Hei TK. Genotoxic mechanisms of asbestos fibers: role of extranuclear targets. Chem Res Toxicol. 2007;20(5): 724-33.

26. Heintz NH, Janssen-Heininger YM, Mossman BT. Asbestos, lung cancers, and mesotheliomas: from molecular approaches to targeting tumor survival pathways. Am J Respir Cell Mol Biol. 2010;42(2):133-9.

27. Martinez VD, Vucic EA, Becker-Santos DD, Gil L, Lam WL. Arsenic exposure and the induction of human cancers. J Toxicol. 2011;2011:431287.

28. Ferro A, Zebedeo CN, Davis C, Ng KW, Pfau JC. Amphibole, but not chrysotile, asbestos induces anti-nuclear autoantibodies and IL-17 in C57BL/ 6 mice. J Immunotoxicol. 2014;11(3):283-90.

29. Zebedeo CN, Davis C, Pena C, Ng KW, Pfau JC. Erionite induces production of autoantibodies and IL-17 in C57BL/6 mice. Toxicol Appl Pharmacol. 2014; 275(3):257-64.

30. El-Zein RA, Young RP, Hopkins RJ, Etzel CJ. Genetic predisposition to chronic obstructive pulmonary disease and/or lung cancer: important considerations when evaluating risk. Cancer Prev Res (Phila). 2012;5(4):522-7.

31. Vermaelen $\mathrm{K}$, Brusselle $\mathrm{G}$. Exposing a deadly alliance: novel insights into the biological links between COPD and lung cancer. Pulm Pharmacol Ther. 2013;26(5):544-54

32. Fan Y, Mao R, Yang J. NF-kappaB and STAT3 signaling pathways collaboratively link inflammation to cancer. Protein Cell. 2013;4(3):176-85.

33. Sekine $Y$, Hata A, Koh E, Hiroshima K. Lung carcinogenesis from chronic obstructive pulmonary disease: characteristics of lung cancer from COPD and contribution of signal transducers and lung stem cells in the 
inflammatory microenvironment. Gen Thorac Cardiovasc Surg. 2014;62(7): 415-21.

34. de Visser KE, Eichten A, Coussens LM. Paradoxical roles of the immune system during cancer development. Nat Rev Cancer. 2006;6(1):24-37.

35. Kitamura T, Qian BZ, Pollard JW. Immune cell promotion of metastasis. Nat Rev Immunol. 2015;15(2):73-86

36. Gajewski TF, Schreiber H, Fu YX. Innate and adaptive immune cells in the tumor microenvironment. Nat Immunol. 2013;14(10):1014-22.

37. Conway EM, Pikor LA, Kung SH, Hamilton MJ, Lam S, Lam WL, Bennewith KL. Macrophages, Inflammation, and Lung Cancer. Am J Respir Crit Care Med. 2016;193(2):116-30.

38. Biragyn A, Lee-Chang C. A new paradigm for an old story: the role of regulatory B cells in cancer. Front Immunol. 2012;3:206.

39. Noy R, Pollard JW. Tumor-associated macrophages: from mechanisms to therapy. Immunity. 2014;41(1):49-61.

40. Brandau S, Dumitru CA, Lang S. Protumor and antitumor functions of neutrophil granulocytes. Semin Immunopathol. 2013;35(2):163-76.

41. Bruno A, Ferlazzo G, Albini A, Noonan DM. A think tank of TINKTTANKs: tumor-infiltrating/tumor-associated natural killer cells in tumor progression and angiogenesis. J Natl Cancer Inst. 2014;106(8):dju200.

42. Nelson BH. CD20+ B cells: the other tumor-infiltrating lymphocytes. J Immunol. 2010;185(9):4977-82.

43. Balkwill F, Montfort A, Capasso M. B regulatory cells in cancer. Trends Immunol. 2013;34(4):169-73.

44. Kim HJ, Cantor H. CD4 T-cell subsets and tumor immunity: the helpful and the not-so-helpful. Cancer Immunol Res. 2014;2(2):91-8

45. Li K, Zhang Q, Zhang Y, Yang J, Zheng J. T-cell-associated cellular immunotherapy for lung cancer. J Cancer Res Clin Oncol. 2015;141(7):1249-58.

46. Lakshmi Narendra B, Eshvendar Reddy K, Shantikumar S, Ramakrishna S. Immune system: a double-edged sword in cancer. Inflamm Res. 2013;62(9): 823-34.

47. Eisenstein EM, Williams CB. The T(reg)/Th17 cell balance: a new paradigm for autoimmunity. Pediatr Res. 2009;65(5 Pt 2):26R-31R.

48. Zhou L, Lopes JE, Chong MM, Ivanov II, Min R, Victora GD, Shen Y, Du J, Rubtsov YP, Rudensky AY, et al. TGF-beta-induced Foxp3 inhibits T(H)17 cell differentiation by antagonizing RORgammat function. Nature. 2008; 453(7192):236-40.

49. Du J, Huang C, Zhou B, Ziegler SF. Isoform-specific inhibition of ROR alpha-mediated transcriptional activation by human FOXP3. J Immunol. 2008;180(7):4785-92.

50. Ziegler SF, Buckner JH. FOXP3 and the regulation of Treg/Th17 differentiation. Microbes Infect. 2009:11(5):594-8.

51. Lee HM, Bautista JL, Hsieh CS. Thymic and peripheral differentiation of regulatory T cells. Adv Immunol. 2011;112:25-71.

52. Halvorsen EC, Mahmoud SM, Bennewith KL. Emerging roles of regulatory T cells in tumour progression and metastasis. Cancer Metastasis Rev. 2014; 33(4):1025-41.

53. Geis AL, Fan H, Wu X, Wu S, Huso DL, Wolfe JL, Sears CL, Pardoll DM, Housseau F. Regulatory T-cell Response to Enterotoxigenic Bacteroides fragilis Colonization Triggers IL17-Dependent Colon Carcinogenesis. Cancer Discov. 2015;5(10):1098-109.

54. Beyer M, Schultze JL. Regulatory T cells in cancer. Blood. 2006;108(3):804-11.

55. Campbell DJ. Control of Regulatory T Cell Migration, Function, and Homeostasis. J Immunol. 2015;195(6):2507-13.

56. Savage PA, Malchow S, Leventhal DS. Basic principles of tumor-associated regulatory T cell biology. Trends Immunol. 2013;34(1):33-40.

57. d'Hennezel E, Piccirillo CA. Analysis of human FOXP3+ Treg cells phenotype and function. Methods Mol Biol. 2011;707:199-218.

58. Francisco LM, Salinas VH, Brown KE, Vanguri VK, Freeman GJ, Kuchroo VK, Sharpe AH. PD-L1 regulates the development, maintenance, and function of induced regulatory T cells. J Exp Med. 2009:206(13):3015-29.

59. Vignali DA, Collison LW, Workman CJ. How regulatory T cells work. Nat Rev Immunol. 2008;8(7):523-32.

60. Okazaki T, Chikuma S, Iwai Y, Fagarasan S, Honjo T. A rheostat for immune responses: the unique properties of PD-1 and their advantages for clinical application. Nat Immunol. 2013;14(12):1212-8

61. He J, Hu Y, Hu M, Li B. Development of PD-1/PD-L1 Pathway in Tumor Immune Microenvironment and Treatment for Non-Small Cell Lung Cancer. Sci Rep. 2015;5:13110.

62. Takenaka MC, Robson S, Quintana FJ. Regulation of the T Cell Response by CD39. Trends Immunol. 2016;37(7):427-39.
63. Vinay DS, Ryan EP, Pawelec G, Talib WH, Stagg J, Elkord E, Lichtor T, Decker WK, Whelan RL, Kumara HM, et al. Immune evasion in cancer: Mechanistic basis and therapeutic strategies. Semin Cancer Biol. 2015;35(Suppl):S185-98.

64. Domagala-Kulawik J, Osinska I, Hoser G. Mechanisms of immune response regulation in lung cancer. Translational Lung Cancer Res. 2014;3(1):15-22.

65. Granville CA, Memmott RM, Balogh A, Mariotti J, Kawabata S, Han W, Lopiccolo J, Foley J, Liewehr DJ, Steinberg SM, et al. A central role for Foxp3+ regulatory T cells in K-Ras-driven lung tumorigenesis. PLoS One. 2009;4(3):e5061.

66. Ganesan AP, Johansson M, Ruffell B, Yagui-Beltran A, Lau J, Jablons DM, Coussens LM. Tumor-infiltrating regulatory $T$ cells inhibit endogenous cytotoxic T cell responses to lung adenocarcinoma. J Immunol. 2013;191(4): 2009-17.

67. Wang W, Hodkinson P, McLaren F, MacKinnon A, Wallace W, Howie S, Sethi T. Small cell lung cancer tumour cells induce regulatory $T$ lymphocytes, and patient survival correlates negatively with FOXP3+ cells in tumour infiltrate. Int J Cancer. 2012;131(6):E928-37.

68. Shimizu K, Nakata M, Hirami Y, Yukawa T, Maeda A, Tanemoto K. Tumorinfiltrating Foxp3+ regulatory $T$ cells are correlated with cyclooxygenase-2 expression and are associated with recurrence in resected non-small cell lung cancer. J Thorac Oncol. 2010;5(5):585-90.

69. Razani-Boroujerdi S, Sopori ML. Early manifestations of NNK-induced lung cancer: role of lung immunity in tumor susceptibility. Am J Respir Cell Mol Biol. 2007;36(1):13-9.

70. Erfani N, Mehrabadi SM, Ghayumi MA, Haghshenas MR, Mojtahedi Z, Ghaderi A, Amani D. Increase of regulatory T cells in metastatic stage and CTLA-4 over expression in lymphocytes of patients with non-small cell lung cancer (NSCLC). Lung Cancer. 2012;77(2):306-11.

71. Schneider T, Kimpfler S, Warth A, Schnabel PA, Dienemann H, Schadendorf D, Hoffmann H, Umansky V. Foxp3(+) regulatory T cells and natural killer cells distinctly infiltrate primary tumors and draining lymph nodes in pulmonary adenocarcinoma. J Thorac Oncol. 2011;6(3):432-8.

72. Black CC, Turk MJ, Dragnev K, Rigas JR. Adenocarcinoma contains more immune tolerance regulatory t-cell lymphocytes (versus squamous carcinoma) in non-small-cell lung cancer. Lung. 2013;191(3):265-70.

73. Smyth MJ, Teng MW, Swann J, Kyparissoudis K, Godfrey DI, Hayakawa Y. CD4 + CD25+ T regulatory cells suppress NK cell-mediated immunotherapy of cancer. J Immunol. 2006;176(3):1582-7.

74. Petersen RP, Campa MJ, Sperlazza J, Conlon D, Joshi MB, Harpole Jr DH, Patz Jr EF. Tumor infiltrating Foxp3+ regulatory T-cells are associated with recurrence in pathologic stage I NSCLC patients. Cancer. 2006;107(12):2866-72.

75. Koyama K, Kagamu H, Miura S, Hiura T, Miyabayashi T, Itoh R, Kuriyama H, Tanaka H, Tanaka J, Yoshizawa H, et al. Reciprocal CD4+ T-cell balance of effector CD62Llow CD4+ and CD62LhighCD25+ CD4+ regulatory T cells in small cell lung cancer reflects disease stage. Clin Cancer Res. 2008;14(21): 6770-9.

76. Reck M, Bondarenko I, Luft A, Serwatowski P, Barlesi F, Chacko R, Sebastian M, Lu H, Cuillerot JM, Lynch TJ. Ipilimumab in combination with paclitaxel and carboplatin as first-line therapy in extensive-disease-small-cell lung cancer: results from a randomized, double-blind, multicenter phase 2 trial. Ann Oncol. 2013;24(1):75-83.

77. Lynch TJ, Bondarenko I, Luft A, Serwatowski P, Barlesi F, Chacko R, Sebastian $M$, Neal J, Lu H, Cuillerot JM, et al. Ipilimumab in combination with paclitaxel and carboplatin as first-line treatment in stage IIIB/V non-small-cell lung cancer: results from a randomized, double-blind, multicenter phase II study. J Clin Oncol Off J Am Soc Clin Oncol. 2012;30(17):2046-54.

78. Brahmer J, Reckamp KL, Baas P, Crino L, Eberhardt WE, Poddubskaya E, Antonia S, Pluzanski A, Vokes EE, Holgado E, et al. Nivolumab versus Docetaxel in Advanced Squamous-Cell Non-Small-Cell Lung Cancer. N Engl J Med. 2015;373(2):123-35

79. Borghaei H, Paz-Ares L, Horn L, Spigel DR, Steins M, Ready NE, Chow LQ, Vokes EE, Felip E, Holgado E, et al. Nivolumab versus Docetaxel in Advanced Nonsquamous Non-Small-Cell Lung Cancer. N Engl J Med. 2015;373(17):1627-39.

80. Guibert N, Mazieres J. Nivolumab for treating non-small cell lung cancer. Expert Opin Biol Ther. 2015;15(12):1789-97.

81. Politi K, Herbst RS. Lung cancer in the era of precision medicine. Clin Cancer Res. 2015;21(10):2213-20.

82. Wang A, Wang Z, Cao Y, Cheng S, Chen H, Bunjhoo H, Xie J, Wang C, Xu Y, Xiong W. CCL2/CCR2-dependent recruitment of Th17 cells but not TC17 cells to the lung in a murine asthma model. Int Arch Allergy Immunol. 2015;166(1):52-62. 
83. Glosson-Byers NL, Sehra S, Stritesky GL, Yu Q, Awe O, Pham D, Bruns HA, Kaplan MH. Th17 cells demonstrate stable cytokine production in a proallergic environment. J Immunol. 2014;193(6):2631-40.

84. Pham D, Sehra S, Sun $\mathrm{X}$, Kaplan MH. The transcription factor Etv5 controls TH17 cell development and allergic airway inflammation. J Allergy Clin Immunol. 2014;134(1):204-14.

85. Tsai HC, Velichko S, Hung LY, Wu R. IL-17A and Th17 cells in lung inflammation: an update on the role of Th17 cell differentiation and IL-17R signaling in host defense against infection. Clin Dev Immunol. 2013;2013: 267971.

86. Song L, Weng D, Dai W, Tang W, Chen S, Li C, Chen Y, Liu F, Chen J. Th17 can regulate silica-induced lung inflammation through an IL-1 beta-dependent mechanism. J Cell Mol Med. 2014;18(9):1773-84.

87. Lu X, McCoy KS, Xu J, Hu W, Chen H, Jiang K, Han F, Chen P, Wang Y. Galectin-9 ameliorates respiratory syncytial virus-induced pulmonary immunopathology through regulating the balance between Th17 and regulatory T cells. Virus Res. 2015;195:162-71.

88. Bystrom J, Al-Adhoubi N, Al-Bogami M, Jawad AS, Mageed RA. Th17 lymphocytes in respiratory syncytial virus infection. Viruses. 2013;5(3):777-91.

89. Vucic EA, Chari R, Thu KL, Wilson IM, Cotton AM, Kennett JY, Zhang M, Lonergan KM, Steiling K, Brown CJ, et al. DNA methylation is globally disrupted and associated with expression changes in chronic obstructive pulmonary disease small airways. Am J Respir Cell Mol Biol. 2014;50(5):912-22.

90. Gaffen SL, Jain R, Garg AV, Cua DJ. The IL-23-IL-17 immune axis: from mechanisms to therapeutic testing. Nat Rev Immunol. 2014;14(9):585-600.

91. Ye J, Livergood RS, Peng G. The role and regulation of human Th17 cells in tumor immunity. Am J Pathol. 2013;182(1):10-20.

92. Ogura H, Murakami M, Okuyama Y, Tsuruoka M, Kitabayashi C, Kanamoto M Nishihara M, Iwakura Y, Hirano T. Interleukin-17 promotes autoimmunity by triggering a positive-feedback loop via interleukin-6 induction. Immunity. 2008;29(4):628-36.

93. Iwakura $Y$, Ishigame H, Saijo S, Nakae S. Functional specialization of interleukin-17 family members. Immunity. 2011;34(2):149-62.

94. Kaabachi W, ben Amor A, Kaabachi S, Rafrafi A, Tizaoui K, Hamzaoui K. Interleukin-17A and -17F genes polymorphisms in lung cancer. Cytokine. 2014:66(1):23-9.

95. Zou W, Restifo NP. T(H)17 cells in tumour immunity and immunotherapy. Nat Rev Immunol. 2010;10(4):248-56.

96. Yang XO, Chang SH, Park H, Nurieva R, Shah B, Acero L, Wang YH, Schluns KS, Broaddus RR, Zhu Z, et al. Regulation of inflammatory responses by IL-17F. J Exp Med. 2008;205(5):1063-75.

97. Xu C, Hao K, Yu L, Zhang X. Serum interleukin-17 as a diagnostic and prognostic marker for non-small cell lung cancer. Biomarkers. 2014;19(4): 287-90.

98. Park H, Li Z, Yang XO, Chang SH, Nurieva R, Wang YH, Wang Y, Hood L, Zhu $Z$, Tian $Q$, et al. A distinct lineage of CD4 T cells regulates tissue inflammation by producing interleukin 17. Nat Immunol. 2005;6(11):1133-41.

99. Vucic EA. Multi-omics characterization of the molecular effects of smoking and chronic inflammation on the lung. Vancouver: University of British Columbia; 2014.

100. Vargas-Rojas MI, Ramirez-Venegas A, Limon-Camacho L, Ochoa L, Hernandez-Zenteno R, Sansores RH. Increase of Th17 cells in peripheral blood of patients with chronic obstructive pulmonary disease. Respir Med. 2011;105(11):1648-54.

101. Chang SH, Mirabolfathinejad SG, Katta H, Cumpian AM, Gong L, Caetano MS, Moghaddam SJ, Dong C. T helper 17 cells play a critical pathogenic role in lung cancer. Proc Natl Acad Sci U S A. 2014;111(15):5664-9.

102. Wei L, Wang H, Yang F, Ding Q, Zhao J. Interleukin-17 potently increases non-small cell lung cancer growth. Mol Med Rep. 2016;13(2):1673-80.

103. Reppert S, Boross I, Koslowski M, Tureci O, Koch S, Lehr HA, Finotto S. A role for T-bet-mediated tumour immune surveillance in anti-IL-17A treatment of lung cancer. Nat Commun. 2011;2:600.

104. Li Q, Han Y, Fei G, Guo Z, Ren T, Liu Z. IL-17 promoted metastasis of nonsmall-cell lung cancer cells. Immunol Lett. 2012;148(2):144-50.

105. Pan B, Shen J, Cao J, Zhou Y, Shang L, Jin S, Cao S, Che D, Liu F, Yu Y. Interleukin-17 promotes angiogenesis by stimulating VEGF production of cancer cells via the STAT3/GIV signaling pathway in non-small-cell lung cancer. Sci Rep. 2015;5:16053.

106. Gu FM, Li QL, Gao Q, Jiang JH, Zhu K, Huang XY, Pan JF, Yan J, Hu JH, Wang

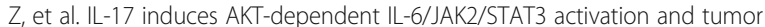
progression in hepatocellular carcinoma. Mol Cancer. 2011;10:150.
107. Wang L, Yi T, Kortylewski M, Pardoll DM, Zeng D, Yu H. IL-17 can promote tumor growth through an IL-6-Stat3 signaling pathway. J Exp Med. 2009; 206(7):1457-64.

108. Adams RH, Alitalo K. Molecular regulation of angiogenesis and lymphangiogenesis. Nat Rev Mol Cell Biol. 2007;8(6):464-78.

109. Chen X, Xie Q, Cheng X, Diao X, Cheng Y, Liu J, Xie W, Chen Z, Zhu B. Role of interleukin-17 in lymphangiogenesis in non-small-cell lung cancer: Enhanced production of vascular endothelial growth factor C in non-small-cell lung carcinoma cells. Cancer Sci. 2010;101(11):2384-90.

110. Chen X, Wan J, Liu J, Xie W, Diao X, Xu J, Zhu B, Chen Z. Increased IL-17-producing cells correlate with poor survival and lymphangiogenesis in NSCLC patients. Lung Cancer. 2010;69(3):348-54.

111. Carmi Y, Rinott G, Dotan S, Elkabets M, Rider P, Voronov E, Apte RN. Microenvironment-derived IL-1 and IL-17 interact in the control of lung metastasis. J Immunol. 2011;186(6):3462-71.

112. Lim C, Savan R. The role of the IL-22/IL-22R1 axis in cancer. Cytokine Growth Factor Rev. 2014;25(3):257-71.

113. Zhang W, Chen Y, Wei H, Zheng C, Sun R, Zhang J, Tian Z. Antiapoptotic activity of autocrine interleukin-22 and therapeutic effects of interleukin-22small interfering RNA on human lung cancer xenografts. Clin Cancer Res. 2008;14(20):6432-9.

114. Martin-Orozco N, Muranski P, Chung Y, Yang XO, Yamazaki T, Lu S, Hwu P, Restifo NP, Overwijk WW, Dong C. T helper 17 cells promote cytotoxic T cell activation in tumor immunity. Immunity. 2009;31(5):787-98.

115. Santegoets SJ, Turksma AW, Suhoski MM, Stam AG, Albelda SM, Hooijberg E, Scheper RJ, van den Eertwegh AJ, Gerritsen WR, Powell Jr DJ, et al. IL-21 promotes the expansion of CD27+ CD28+ tumor infiltrating lymphocytes with high cytotoxic potential and low collateral expansion of regulatory $T$ cells. J Transl Med. 2013;11:37.

116. Zeng R, Spolski R, Finkelstein SE, Oh S, Kovanen PE, Hinrichs CS, Pise-Masison CA, Radonovich MF, Brady JN, Restifo NP, et al. Synergy of IL-21 and IL-15 in regulating CD8+ T cell expansion and function. J Exp Med. 2005;201(1):139-48,

117. Ye ZJ, Zhou Q, Gu YY, Qin SM, Ma WL, Xin JB, Tao XN, Shi HZ. Generation and differentiation of IL-17-producing CD4+ T cells in malignant pleural effusion. J Immunol. 2010;185(10):6348-54.

118. Galon J, Pages F, Marincola FM, Thurin M, Trinchieri G, Fox BA, Gajewski TF, Ascierto PA. The immune score as a new possible approach for the classification of cancer. J Transl Med. 2012;10:1.

119. Fridman WH, Pages F, Sautes-Fridman C, Galon J. The immune contexture in human tumours: impact on clinical outcome. Nat Rev Cancer. 2012;12(4):298-306.

120. Galon J, Mlecnik B, Bindea G, Angell HK, Berger A, Lagorce C, Lugli A, Zlobec I, Hartmann A, Bifulco C, et al. Towards the introduction of the 'Immunoscore' in the classification of malignant tumours. J Pathol. 2014; 232(2):199-209.

121. Donnem T, Kilvaer TK, Andersen S, Richardsen E, Paulsen EE, Hald SM, Al-Saad S, Brustugun OT, Helland A, Lund-Iversen M, et al. Strategies for clinical implementation of TNM-Immunoscore in resected nonsmall-cell lung cancer. Ann Oncol. 2015.

122. Bryant C, Suen H, Brown R, Yang S, Favaloro J, Aklilu E, Gibson J, Ho PJ, lland $H$, Fromm $P$, et al. Long-term survival in multiple myeloma is associated with a distinct immunological profile, which includes proliferative cytotoxic T-cell clones and a favourable Treg/Th17 balance. Blood Cancer J. 2013:3:e148.

123. Zhang W, Hou F, Zhang Y, Tian Y, Jiao J, Ma D, Kong B, Cui B. Changes of Th17/Tc17 and Th17/Treg cells in endometrial carcinoma. Gynecol Oncol. 2014;132(3):599-605.

124. Wang X, Wang L, Mo Q, Dong Y, Wang G, Ji A. Changes of Th17/Treg cell and related cytokines in pancreatic cancer patients. Int J Clin Exp Pathol. 2015;8(5):5702-8.

125. Duan MC, Zhong XN, Liu GN, Wei JR. The Treg/Th17 paradigm in lung cancer. J Immunol Res. 2014;2014:730380.

126. Li S, Li Y, Qu X, Liu X, Liang J. Detection and significance of TregFoxP3(+) and Th17 cells in peripheral blood of non-small cell lung cancer patients. Arch Med Sci. 2014;10(2):232-9.

127. Kleinewietfeld M, Hafler DA. The plasticity of human Treg and Th17 cells and its role in autoimmunity. Semin Immunol. 2013;25(4):305-12.

128. Szodoray P, Nakken B, Barath S, Csipo I, Nagy G, El-Hage F, Osnes LT, Szegedi G, Bodolay E. Altered Th17 cells and Th17/regulatory T-cell ratios indicate the subsequent conversion from undifferentiated connective tissue disease to definitive systemic autoimmune disorders. Hum Immunol. 2013; 74(12):1510-8 
129. Xing Q, Wang B, Su H, Cui J, Li J. Elevated Th17 cells are accompanied by FoxP3+ Treg cells decrease in patients with lupus nephritis. Rheumatol Int. 2012;32(4):949-58.

130. Astry B, Venkatesha SH, Moudgil KD. Involvement of the IL-23/IL-17 axis and the Th17/Treg balance in the pathogenesis and control of autoimmune arthritis. Cytokine. 2015;74(1):54-61.

131. Su ZJ, Yu XP, Guo RY, Ming DS, Huang LY, Su ML, Deng Y, Lin ZZ. Changes in the balance between Treg and Th17 cells in patients with chronic hepatitis B. Diagn Microbiol Infect Dis. 2013;76(4):437-44.

132. Xu L, Gong Y, Wang B, Shi K, Hou Y, Wang L, Lin Z, Han Y, Lu L, Chen D, et al. Randomized trial of autologous bone marrow mesenchymal stem cells transplantation for hepatitis B virus cirrhosis: regulation of Treg/Th17 cells. J Gastroenterol Hepatol. 2014;29(8):1620-8.

133. Pang N, Zhang F, Ma X, Zhu Y, Zhao H, Xin Y, Wang S, Chen Z, Wen H, Ding J. TGF-beta/Smad signaling pathway regulates Th17/Treg balance during Echinococcus multilocularis infection. Int Immunopharmacol. 2014;20(1):248-57.

134. Gil JH, Seo JW, Cho MS, Ahn JH, Sung HY. Role of Treg and TH17 cells of the gastric mucosa in children with Helicobacter pylori gastritis. J Pediatr Gastroenterol Nutr. 2014;58(2):245-51.

135. Bailey SR, Nelson MH, Himes RA, Li Z, Mehrotra S, Paulos CM. Th17 cells in cancer: the ultimate identity crisis. Front Immunol. 2014;5:276.

136. Guery L, Huques S. Th17 Cell Plasticity and Functions in Cancer Immunity. Biomed Res Int. 2015;2015:314620.

137. Duan MC, Han W, Jin PW, Wei YP, Wei Q, Zhang LM, Li JC. Disturbed Th17/ Treg balance in patients with non-small cell lung cancer. Inflammation. 2015;38(6):2156-65.

138. Prado-Garcia H, Romero-Garcia S, Rumbo-Nava U, Lopez-Gonzalez JS. Predominance of Th17 over regulatory T-cells in pleural effusions of patients with lung cancer implicates a proinflammatory profile. Anticancer Res. 2015; 35(3):1529-35

139. Yang G, Li H, Yao Y, Xu F, Bao Z, Zhou J. Treg/Th17 imbalance in malignant pleural effusion partially predicts poor prognosis. Oncol Rep. 2015;33(1):478-84.

140. Crusz SM, Balkwill FR. Inflammation and cancer: advances and new agents. Nat Rev Clin Oncol. 2015:12(10):584-96.

141. Crowley E, Di Nicolantonio F, Loupakis F, Bardelli A. Liquid biopsy: monitoring cancer-genetics in the blood. Nat Rev Clin Oncol. 2013;10(8): 472-84.

142. Newell EW, Davis MM. Beyond model antigens: high-dimensional methods for the analysis of antigen-specific T cells. Nat Biotechnol. 2014;32(2):149-57.

143. Kroeger DR, Milne K, Nelson BH. Tumor-infiltrating plasma cells are associated with tertiary lymphoid structures, cytolytic T-cell responses, and superior prognosis in ovarian cancer. Clin Cancer Res. 2016;22(12):3005-15.

144. Tumeh PC, Harview CL, Yearley JH, Shintaku IP, Taylor EJ, Robert L, Chmielowski B, Spasic M, Henry G, Ciobanu V, et al. PD-1 blockade induces responses by inhibiting adaptive immune resistance. Nature. 2014;515(7528):568-71.

145. Kryczek I, Wu K, Zhao E, Wei S, Vatan L, Szeliga W, Huang E, Greenson J, Chang A, Rolinski J, et al. IL-17+ regulatory T cells in the microenvironments of chronic inflammation and cancer. J Immunol. 2011;186(7):4388-95.

146. Du R, Zhao H, Yan F, Li H. IL-17 + Foxp3+ T cells: an intermediate differentiation stage between Th17 cells and regulatory T cells. J Leukoc Biol. 2014;96(1):39-48.

147. Hovhannisyan Z, Treatman J, Littman DR, Mayer L. Characterization of interleukin-17-producing regulatory T cells in inflamed intestinal mucosa from patients with inflammatory bowel diseases. Gastroenterology. 2011; 140(3):957-65

148. Li L, Boussiotis VA. The role of IL-17-producing Foxp3+ CD4+ T cells in inflammatory bowel disease and colon cancer. Clin Immunol. 2013;148(2): 246-53.

149. Huang C, Fu ZX. Localization of IL-17 + Foxp3+ T cells in esophageal cancer. Immunol Invest. 2011;40(4):400-12.

150. Girardin A, McCall J, Black MA, Edwards F, Phillips V, Taylor ES, Reeve AE, Kemp RA. Inflammatory and regulatory T cells contribute to a unique immune microenvironment in tumor tissue of colorectal cancer patients. Int J Cancer. 2013;132(8):1842-50.

151. Phillips JD, Knab LM, Blatner NR, Haghi L, DeCamp MM, Meyerson SL, Heiferman MJ, Heiferman JR, Gounari F, Bentrem DJ, et al. Preferential expansion of pro-inflammatory Tregs in human non-small cell lung cancer. Cancer Immunol Immunother. 2015;64(9):1185-91.
152. Smyth MJ, Ngiow SF, Teng MW. Targeting regulatory T cells in tumor immunotherapy. Immunol Cell Biol. 2014:92(6):473-4.

153. Lin H, Song P, Zhao Y, Xue LJ, Liu Y, Chu CQ. Targeting Th17 Cells with Small Molecules and Small Interference RNA. Mediators Inflamm. 2015;2015:290657.

154. Onishi H, Morisaki T, Katano M. Immunotherapy approaches targeting regulatory T-cells. Anticancer Res. 2012;32(3):997-1003.

155. Rider P, Carmi Y, Voronov E, Apte RN. Interleukin-1alpha. Semin Immunol. 2013:25(6):430-8.

156. Xu J, Yin Z, Cao S, Gao W, Liu L, Yin Y, Liu P, Shu Y. Systematic review and meta-analysis on the association between IL-1B polymorphisms and cancer risk. PLoS One. 2013;8(5):e63654.

157. Yu Z, Liu Q, Huang C, Wu M, Li G. The interleukin 10-819C/T polymorphism and cancer risk: a HuGE review and meta-analysis of 73 studies including 15,942 cases and 22,336 controls. OMICS. 2013:17(4):200-14.

158. Dennis KL, Blatner NR, Gounari F, Khazaie K. Current status of interleukin-10 and regulatory T-cells in cancer. Curr Opin Oncol. 2013;25(6):637-45.

159. Oft M. IL-10: master switch from tumor-promoting inflammation to antitumor immunity. Cancer Immunol Res. 2014;2(3):194-9.

160. Zhang J, Patel L, Pienta KJ. CC chemokine ligand 2 (CCL2) promotes prostate cancer tumorigenesis and metastasis. Cytokine Growth Factor Rev. 2010;21(1):41-8

161. Steiner JL, Murphy EA. Importance of chemokine (CC-motif) ligand 2 in breast cancer. Int J Biol Markers. 2012;27(3):e179-85.

162. Dhawan $P$, Richmond A. Role of CXCL1 in tumorigenesis of melanoma. J Leukoc Biol. 2002;72(1):9-18.

163. Verbeke H, Geboes K, Van Damme J, Struyf S. The role of CXC chemokines in the transition of chronic inflammation to esophageal and gastric cancer. Biochim Biophys Acta. 2012;1825(1):117-29.

164. Aliper AM, Frieden-Korovkina VP, Buzdin A, Roumiantsev SA, Zhavoronkov A. A role for G-CSF and GM-CSF in nonmyeloid cancers. Cancer Med. 2014;3(4):737-46.

165. Shojaei F, Wu X, Qu X, Kowanetz M, Yu L, Tan M, Meng YG, Ferrara N. G-CSF-initiated myeloid cell mobilization and angiogenesis mediate tumor refractoriness to anti-VEGF therapy in mouse models. Proc Natl Acad Sci U S A. 2009;106(16):6742-7.

166. Rodvold JJ, Mahadevan NR, Zanetti M. Lipocalin 2 in cancer: when good immunity goes bad. Cancer Lett. 2012;316(2):132-8.

167. Leng X, Wu Y, Arlinghaus RB. Relationships of lipocalin 2 with breast tumorigenesis and metastasis. J Cell Physiol. 2011;226(2):309-14.

168. Bose SK, Gibson W, Bullard RS, Donald CD. PAX2 oncogene negatively regulates the expression of the host defense peptide human beta defensin-1 in prostate cancer. Mol Immunol. 2009;46(6):1140-8.

169. Yang D, Biragyn A, Hoover DM, Lubkowski J, Oppenheim JJ. Multiple roles of antimicrobial defensins, cathelicidins, and eosinophil-derived neurotoxin in host defense. Annu Rev Immunol. 2004;22:181-215.

\section{Submit your next manuscript to BioMed Central and we will help you at every step:}

- We accept pre-submission inquiries

- Our selector tool helps you to find the most relevant journal

- We provide round the clock customer support

- Convenient online submission

- Thorough peer review

- Inclusion in PubMed and all major indexing services

- Maximum visibility for your research

Submit your manuscript at www.biomedcentral.com/submit 